Article

\title{
Greenockite Whiskers from the Bytom Burned Coal Dump, Upper Silesia, Poland
}

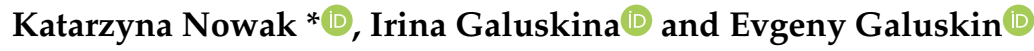 \\ Institute of Earth Sciences, Faculty of Natural Sciences, University of Silesia, Bankowa 12, 40-007 Katowice, \\ Poland; irina.galuskina@us.edu.pl (I.G.); evgeny.galuskin@us.edu.pl (E.G.) \\ * Correspondence: katarzyna009b@interia.pl
}

Received: 3 April 2020; Accepted: 20 May 2020; Published: 22 May 2020

check for updates

\begin{abstract}
Orange greenockite (CdS) aggregates were found in a small fumarole at a burned coal dump near Bytom, Upper Silesia, Poland and were studied using a variety of techniques in order to determine their chemistry, morphology, and most importantly, the mechanism of crystal growth. Greenockite rods, wires, and whiskers with bismuth drops on crystal tops are predominant in these aggregates. Greenockite rods oriented sub-perpendicular to the substrate surface. The rod thickness reaches 5-6 $\mu \mathrm{m}$ and about $10 \mu \mathrm{m}$ in length. The catalyst bismuth drop has a diameter comparable to the rod thickness. Fiber forms (wires and whiskers) are sub-parallel to the substrate surface. The thickness of these forms is usually less than $2 \mu \mathrm{m}$, and the length can be close to $1 \mathrm{~mm}$. The bismuth drop diameter can show a large excess over the fiber thickness. Catalyst drops on the tops of whiskers began to change their form dynamically and exploded, spraying bismuth under the electron beam effect. Rods grow along the [01-10] direction, and whiskers and wires (axial forms) along the [0001] direction. Greenockite rod crystals, carrying on top a relatively homogenous bismuth catalyst drop, were formed on the heated substrate according to the VLS (vapor-liquid-solid) mechanism at temperatures not lower than $270{ }^{\circ} \mathrm{C}$. Greenockite whiskers and wires grew just above of the substrate surface according to the VQS (vapor-quasiliquid-solid) mechanism at temperatures lower than $200{ }^{\circ} \mathrm{C}$. These mechanisms of growth have very rarely been recorded to occur in nature and even less so in burning coal dumps. The cooperative growth effects of the fiber greenockite crystals were also described.
\end{abstract}

Keywords: greenockite; whisker; bismuth drop; VLS mechanism; VQS mechanism; coal dump; Bytom; Poland

\section{Introduction}

Burned coal dumps, being the objects of numerous applied geological, ecological, and technological investigations, are also specific "technogenic laboratories", in which, in real-time processes of mineral phase formation, analogical ones to those in volcanic and metamorphic processes take place. Results of the investigation of these processes and their products can be used in different fields of knowledge from the science of meteorites to the growth of crystals.

Samples containing orange crusts with a few $\mathrm{mm}^{2}$ area were collected on a burned coal dump near Bytom town in the Upper Silesia, Poland (Figure 1). These crusts are represented by greenockite, $\mathrm{CdS}$, which forms various morphological types, among which rods, wires, and whiskers [1] with bismuth drops on crystal tops are predominant (Figure 2). 


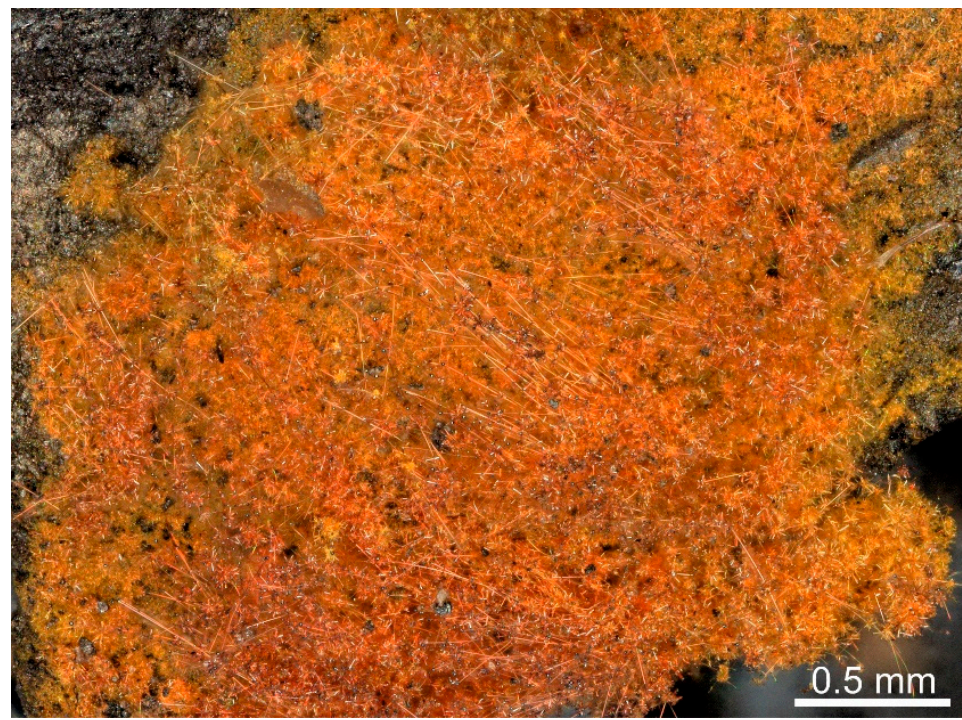

Figure 1. Greenockite crust with well-visible whiskers (fiber form of crystals).
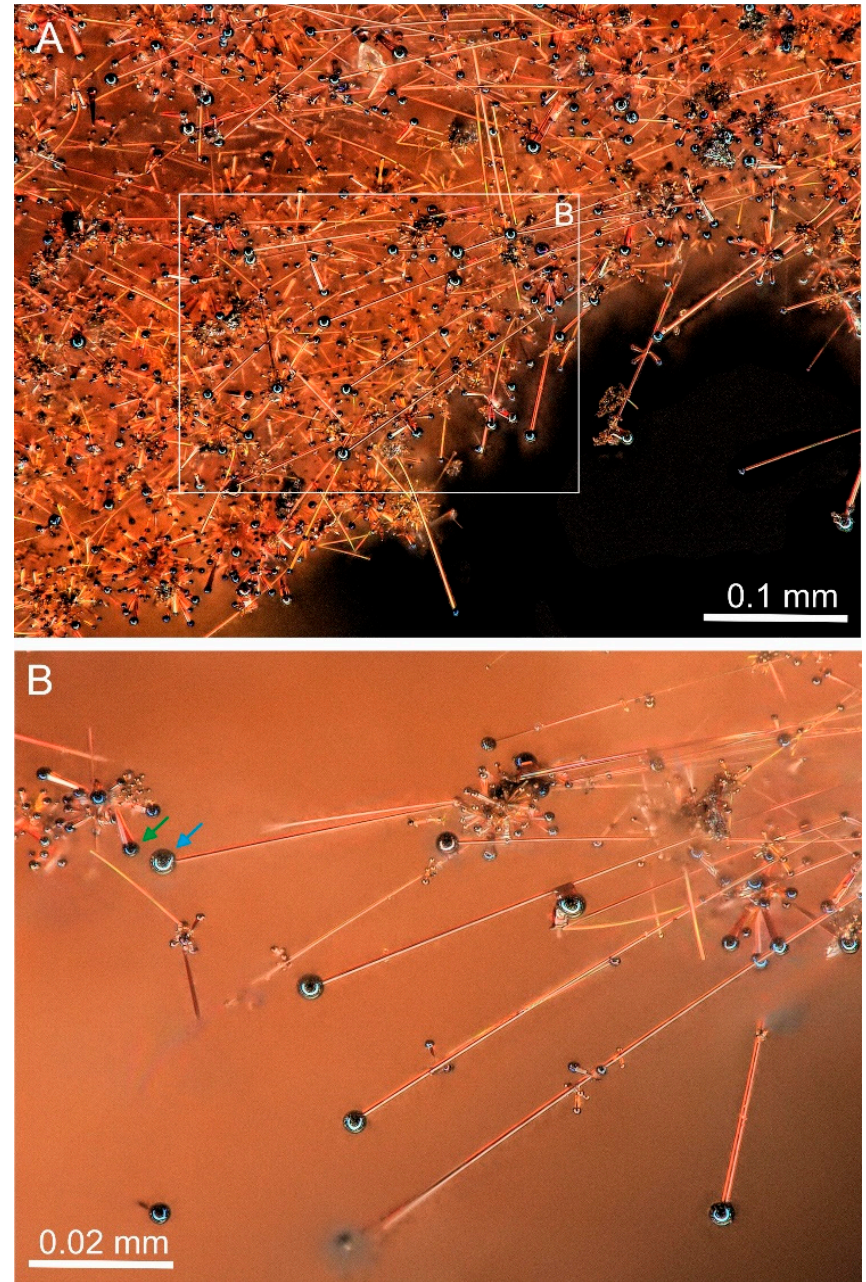

Figure 2. Greenockite whiskers with bismuth drops on the tops. (A) General view, the fragment magnified in Figure 2B is outlined by the frame. (B) Drop diameter on the top of the whiskers is greater by several times than the crystal diameter (blue arrow). Drop diameter on the top of the short-rod crystals, the thickness of which increases step by step towards the crystal top, is comparable with the crystal diameter (green arrow). 
These morphological forms allow an assumption of their formation according to the VLS (vapor-liquid-solid) mechanism, a required condition of which is a presence of a metallic drop (catalyst) on the crystal top for support of its growth. For the first time, this mechanism was proposed by Wagner and Eliis in 1964 [2], and at present, it is widely used for the synthesis of anisometric needle-like and fiber crystals of a nanometric size [3-7].

In this paper, we present data on the morphology and composition of whisker and wire forms of greenockite from a burned coal dump near Bytom town, Upper Silesia, Poland, and discuss the mechanisms of their formation. Additionally, we describe the effects of cooperative growth of whiskers, and the unusual phenomena taking place in the catalyst drops induced by an electron beam of a scanning electron microscope.

Whiskers that are formed by the VLS mechanism have rarely been observed in nature and less so in burning coal dumps, mostly because of their bad preservation in secondary geological processes. The VLS growth mechanism was assumed for needle-like crystals of gersdorfite, NiAsS, from the arsenide ore of Schneeberg, Germany [8] and for zincite, $\mathrm{ZnO}$, from cavities in gabbro-syenites of the Chatkal Range, Uzbekistan [9]. Only a few examples of needle-like crystals from burned coal dumps, the formation of which is linked with VLS mechanism, have been mentioned in the literature: Germanium sulfide, $\mathrm{GeS}_{2}$ (catalyst drop $\mathrm{S}+\mathrm{Ge}$ ) from the burned dumps of anthracite granulate from Foretville, Pennsylvania, USA $[10,11]$ and greenockite (catalyst drop Bi $+\mathrm{Te}$ ) from coal dumps in the Czech Republic [12-14].

During World War II, radar installations often inexplicably failed. It turned out that long metal hairs appeared on the tin solder, which caused short circuits. These metal fibers were called whiskers. Cadmium and tin whiskers were first described in the late 1940s in telephone sets [15,16]. At present, whiskers are defined as extremely elongated crystals in one direction $[17,18]$, the morphology of which is not forced by crystallographic directions but by environmental conditions and the mechanism of mineral growth [17]. In 1964, Wagner and Ellis proposed a whisker growth mechanism that did not require a screw dislocation; this is the VLS (vapor-liquid-solid) mechanism. In their work, they explained the growth of $\mathrm{Si}$ whiskers with a drop of liquid $\mathrm{Au}$ on the top of the crystal. The growth through the VLS mechanism can be divided into stages. In the first stage, gas components are transported and absorbed by the liquid catalyst. The next stage is provided for the diffusion of primary gas components and their crystallization at the crystal-liquid interface. Today, the concept of the VLS mechanism has been widely developed. Analogies of the VLS mechanism have been elaborated, such as VSS (vapor-solid-solid), VQS (vapor-quasiliquid-solid), and SLS (solution-liquid-solid) [3,4,19-24].

\section{Occurrence}

Greenockite whiskers were detected in the immediate vicinity of a small fumarole at a burned coal dump near Bytom, Upper Silesia, Poland. The dump has an oval form of about $350 \mathrm{~m}$ in length and a wideness of about $120 \mathrm{~m}$ (Figure 3). The spontaneous fire began at the west part of the dump and the fire front gradually moved east. The temperature was measured at a depth of $20 \mathrm{~cm}$, which changed in the range from 78 to $692^{\circ} \mathrm{C}$ along the dump. A relatively large fumarole $(50 \times 100 \mathrm{~cm}$ in size) (Figure 3) was in the area of the highest temperatures, where small samples with orange crusts were collected (Figure 1). Interestingly, the temperature measured in this place directly above the fumarole was much lower than $158^{\circ} \mathrm{C}$. It is necessary to note that besides mining waste and coal fragments, an abundance of industrial and building wastes are also found on the dump. 


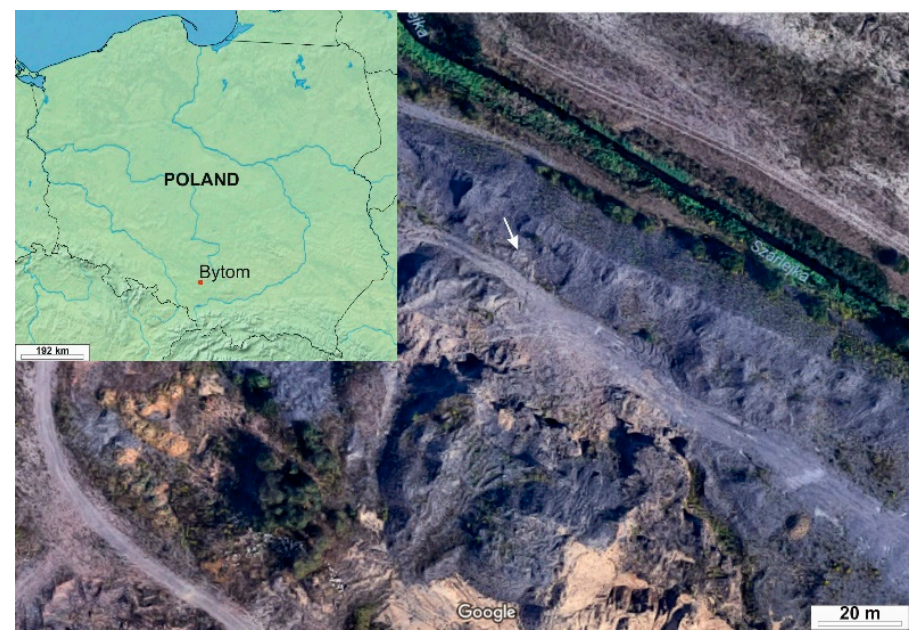

Figure 3. Coal dumps near Bytom town, where the greenockite samples were collected (the arrow).

\section{Methods}

The morphology of the greenockite crystals and their semi-quantitative composition were studied using a scanning electron microscope: Phenom XL with an EDS (energy-dispersive X-ray spectrometer) detector and Philips XL 30 ESEM with an EDS (EDAX type Sapphire) (Institute of Earth Science, Faculty of Natural Sciences, University of Silesia, Katowice, Poland). Quantitative analysis of the chemical composition of greenockite crystals and the catalyst drop was carried out at the microprobe analyzer CAMECA SX100 (Polish Geological Institute, National Research Institute, Warsaw, Poland) at $15 \mathrm{kV}$ and $20 \mathrm{nA}$, beam size $\sim 1 \mu \mathrm{m}$. Lines and standards: $\mathrm{Pb} M \beta$, galena; $\mathrm{Cd} L \alpha, \mathrm{SK} \alpha, \mathrm{CdS} ; \mathrm{Bi} M \beta$, $\mathrm{Bi}_{2} \mathrm{Se}_{3} ; \mathrm{ZnK} \alpha, \mathrm{ZnS} ; \mathrm{Sb} L \alpha$, InSb; SeL $\beta, \mathrm{ZnSe}$.

The Raman spectrum of greenockite was collected on a confocal Raman microscope WITec alpha 300R (Institute of Earth Science, Faculty of Natural Science, University of Silesia, Katowice, Poland) equipped with a 532-nm laser and a CCD camera operating at $-61{ }^{\circ} \mathrm{C}$. The Raman signal was fed to a monochromator with a gratification of $600 \mathrm{~mm}^{-1}$ using an optical fiber with a working diameter of $30 \mu \mathrm{m}$. The laser power on the sample was $\sim 20 \mathrm{~mW}$. The measurements were made at an integration time of $3 \mathrm{~s}$ with an accumulation of 20 scans and a resolution of $3 \mathrm{~cm}^{-1}$. The monochrome was calibrated on a silicon wafer using a Raman scattering line $\left(520.7 \mathrm{~cm}^{-1}\right)$.

X-ray powder diffraction data were obtained using a PANalytical X'Pert PRO MPD PW 3040/60 powder diffractometer and placing the sample on a silicon disk to reduce the background (Institute of Earth Science, Faculty of Natural Sciences, University of Silesia, Katowice, Poland). The diffractometer is equipped with a copper tube using $\mathrm{CuK} \alpha$ radiation and an $\mathrm{X}^{\prime} \mathrm{Celerator}$ detector. The $\mathrm{X}$-ray powder diffraction data were refined in the HighScore + software of Panalytical (version 4.6) using the latest ICDD pattern database, PDF $4^{+}$(version 2014) and, incidentally, the ICSD pattern templates (version 3.5 from 2015). The unit cell parameters were refined using the Rietveld method [25]. ICP-MS (inductively coupled plasma mass spectrometry) analyses were performed in the ACME Laboratory in Vancouver, $\mathrm{BC}$, Canada. The measurements were carried out according to the AQ250_EXT procedure using a $0.5 \mathrm{~g}$ sample after modified aqua regia digestion $\left(1: 1: 1 \mathrm{HNO}_{3}: \mathrm{HCl}: \mathrm{H}_{2} \mathrm{O}\right)$.

More than 200 images obtained from the scanning electron microscopes were used for measurement of the length and thickness of the anisometric crystals (rods, whiskers, and wires) and the catalyst drop diameter. The measurement results are presented in the plots (Figures 4 and 5). Each point on the plot corresponds to one crystal, for which a measurement was performed. 


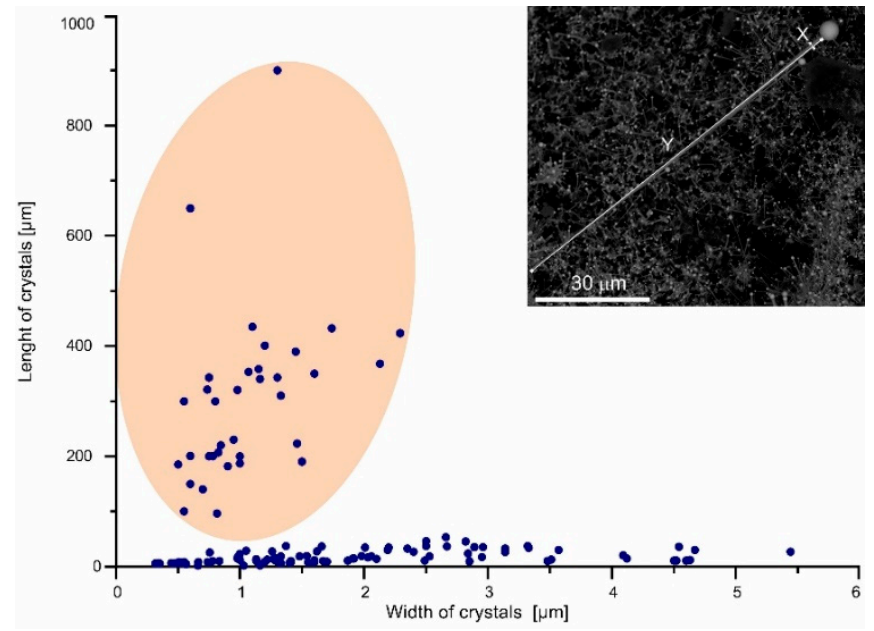

Figure 4. Diagram of the thickness to length ratio of crystals. There are two morphological types: whiskers-wires (light-orange area) and rods. Wire forms $(<<0.5 \mu \mathrm{m})$ are presented incompletely because of the difficulty of the measurements of bend and twisted forms.

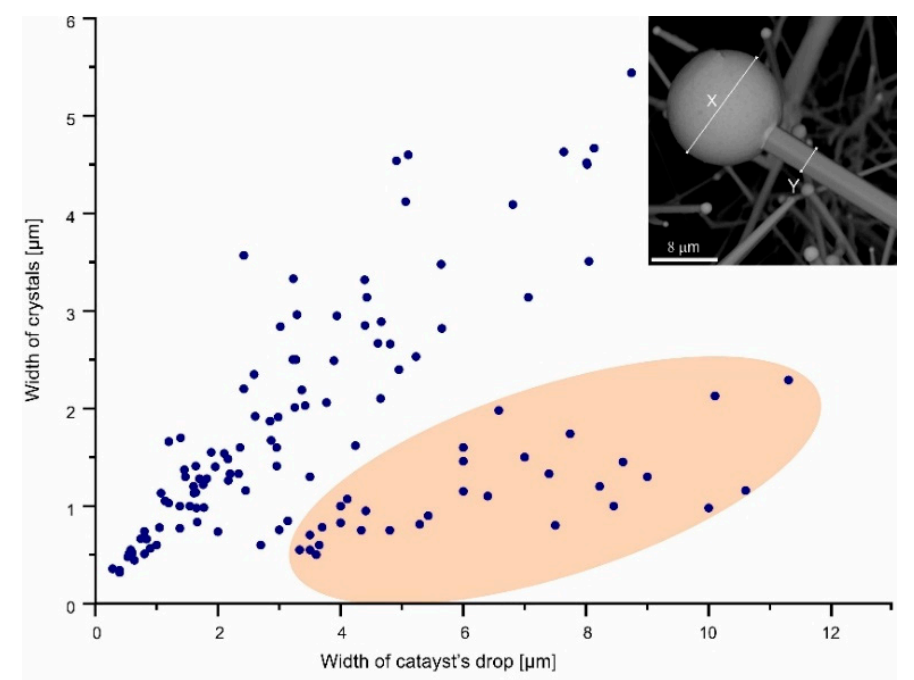

Figure 5. Diagram of the thickness of crystals to the drop diameter on the top of the same crystals. The drop diameter to the thickness of the crystal ratio is $4-5$ times larger for whiskers (pink area), whereas this ratio for rods ranges from 1.2 to 1.7. Data for wires (thickness $>>0.5 \mu \mathrm{m}$ ) is incomplete because of bad preservation and technical problems during measurements.

\section{Results}

Around small gaseous channels in porous burned-out rocks, inhomogeneous greenockite mineralization is observed (Figures 6 and 7A). The mineralization is formed mainly by fine non-stationary elongated forms, often with elements of a skeletal structure and bismuth drops (catalyst drop) on the top of these crystals.

Rare individual greenockite crystal, $0.5-3 \mu \mathrm{m}$ in size, formed by prism $\{01-10\}$, pyramid $\{02-21\}$, and pedion $\{000-1\}$ (Figure 7B), and also splitting greenockite crystals of the two morphological types, sheaf-like (splitting of $\{01-10\}$ prism, Figure 7C) and "flower" type (splitting of (0001) or (000-1) faces (Figure 7D), are noted.

Strongly anisotropic linear "one-dimensional" forms, including greenockite rods, whiskers, and wires, which were the main objects of this investigation, occur only in relatively thick orange greenockite crusts having a two-level structure (Figures 1, 2 and 8A). Greenockite rods, 
oriented sub-perpendicular to the substrate, grow on a porous aggregate of burnt-out coal relics, dolomite, iron oxides, and alumosilicate fragments (Figure 8A,B).
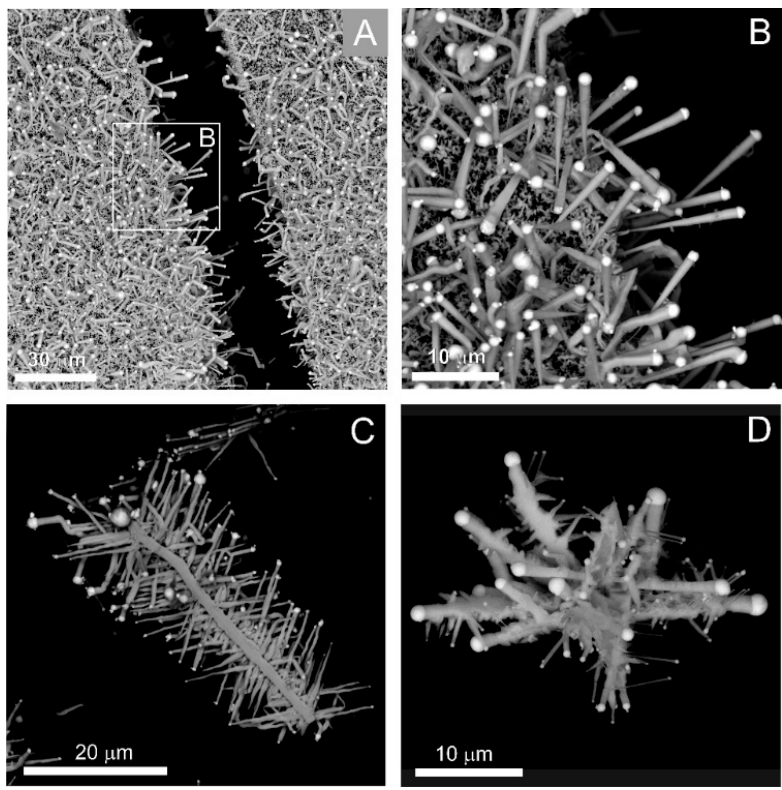

Figure 6. Types of non-stationary greenockite forms. (A,B) Fine crusts formed by rods oriented randomly with the bismuth drop on the top; (B) Magnified fragment shown in Figure 6A in the frame-well-visible rods grow on the substrate covered by nanometric elongated greenockite crystals (bright). (C) Skeletal aggregate on the burned-out coal substrate (black). (D) Intergrowth of greenockite rods with nanometric fibers of the second generation. BSE images.
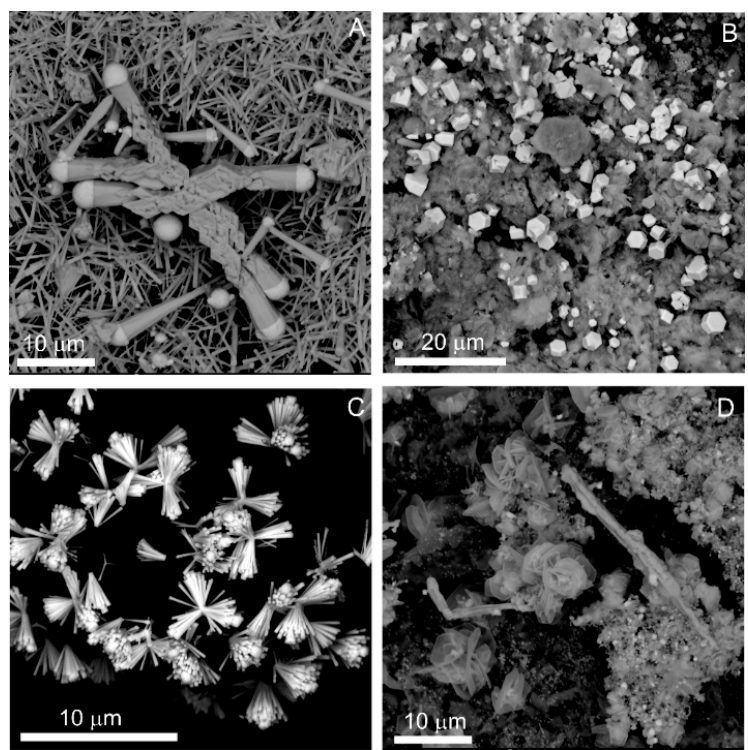

Figure 7. (A) Short rods with elements of skeletal growth laying on greenockite "straw"; (B) idiomorphic greenockite crystals formed by $\{000-1\},\{01-10\}$, and $\{02-21\}$ occur on the substrate represented by a mixture of silicate minerals, quartz, dolomite, iron oxides, and carbonaceous matter; (C) sheaf-like greenockite crystals; (D) flower-type greenockite crystal (at the center of image), nanometric bismuth drops are visible in the bottom right part of the image. BSE images. 

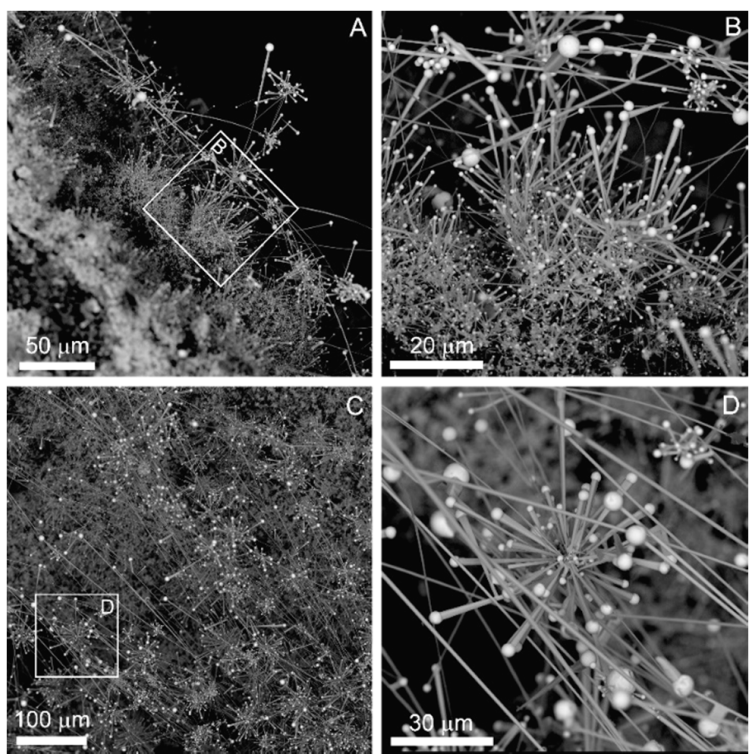

Figure 8. Two main fiber morphological types of greenockite (whiskers and rods) occurring in relatively thick (two-level) crusts. (A,C) Common view: side view (A), top view (C), fragments magnified in Figure 8B,D are shown in frames. (B) Rods forming a radiating aggregate of crystals oriented sub-perpendicular to the substrate. (D) Radiating aggregate of rods growing on fiber crystal. BSE images.

Rods often form radiating aggregate growing from one point (Figure 9A). The rod thickness reaches 5-6 $\mu \mathrm{m}$ and about $10 \mu \mathrm{m}$ in length (Figures 4 and 9). The catalyst bismuth drop has a diameter comparable to the rod thickness and the rod to drop diameter ratio is usually less than 1.5 (Figure 5). Relatively fine rods less than $1 \mu \mathrm{m}$ in thickness have a rounded cross-section, whereas bigger ones have well-marked faces and exhibit a tendency for an increased thickness towards the catalyst drop (Figure 9A). A cross-section of such thick rods is rectangular, which by the analogy of synthetic greenockite whiskers $[5-7,20]$ allows confirmation that they are elongated along [01-10] and facetted by faces close to pyramid $\{2-120\}$ and pedions $\{0001\}$ and $\{000-1\}$ (Figure 9A,B). the edges of such crystals are often cut off by the micro-faces of a hexagonal pyramid (Figure 9). It is rare that a change of the rod growth direction can be observed, which is accompanied by a change of the cross-section to hexagonal, i.e., growth comes in the direction [0001] (Figure 9B).
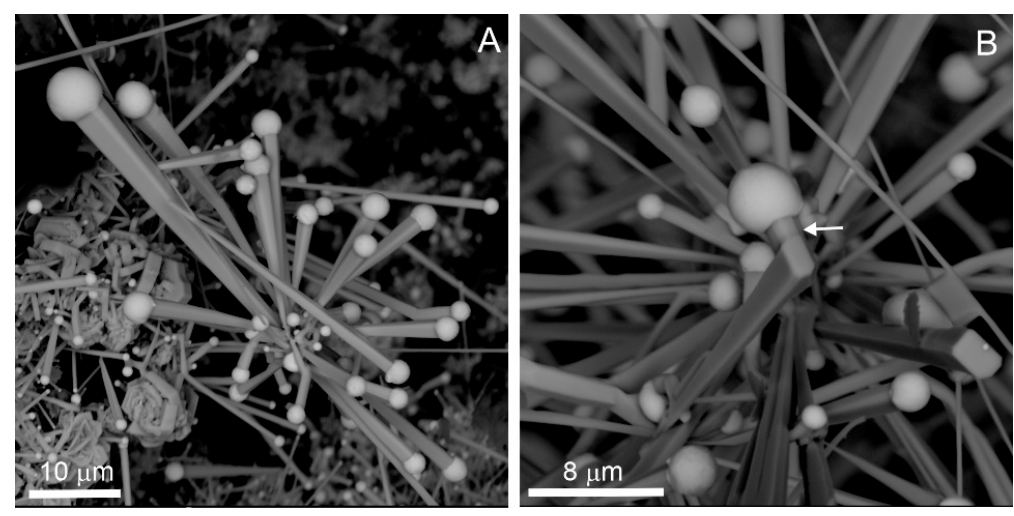

Figure 9. Morphology of rods. (A) Crystals with a rectangular cross-section expanding from base to top, elongated along [01-10]. Bismuth drops have diameters 1.2-1.5 times bigger than the crystal thickness, at the left corner-greenockite crystals of the "flower" type. (B) Change of the crystal growth direction from [01-10] to [0001] (shown by arrow). BSE images. 
It is rare that rods exhibit evidence of morphology changes reflected in the specific character of their crystal growth. Faces with an inhomogeneous skeletal structure were noted, whereas the near-edge area of these faces are smooth and the central part is strongly rough (Figure 10A,B). Peculiar intermediate non-facetted zones between the bismuth drop and crystal top are often observed (Figure 10C,F), which probably is connected with a decrease of the catalyst drop diameter. In the rare case, we observed a formation of rods of the second generation elongated along the [01-10] "mother rod", which has a different morphology depending on the growth direction on [0001] or [000,1] (Figure 10D). Sometimes, the diameter changes of the second-generation rods elongated on [0001] are noted (Figure 10E). Such diameter variations are non-synchronic and rather connected with changes of the bismuth drop diameter during growth.
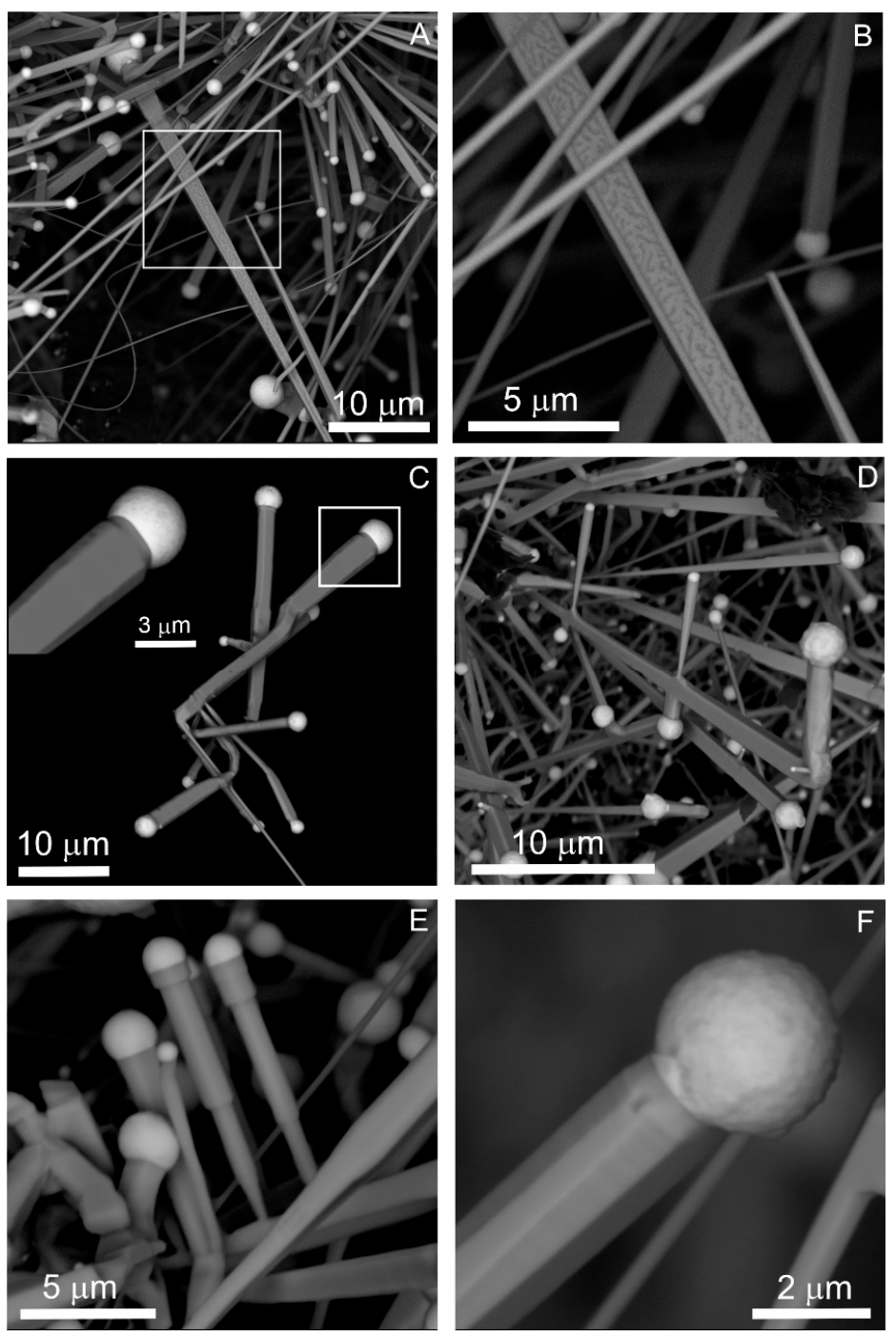

Figure 10. (A,B) Rod with a specific microrelief: (A) common view, fragments magnified in Figure 10B are shown in the frame; (B) magnified fragment. (C) The thinned intermediate zone between the drop and crystal, which is represented by wire at the base. Magnified fragment of the crystal top in the inset. (D) Branches (rods) of the second generation elongated along [0001] on the main rod: the second-generation rods expanding to the top with a rounded cross-section are directed upward (growth direction along [0001]) and the short thick rod is directed downward (growth direction along $[000,1])$. (E) Sharp asynchronous diameter changes of identically oriented crystals of the second generation elongated along [0001] growing on crystal elongated along [01-10]. (F) Rod with an octagonal cross-section elongated along [01-10]. BSE images. 
The second level of greenockite crust is presented by fiber forms, which are sub-parallel to the substrate surface, and are visible both in the optical (Figures 1 and 2) and BSE images (Figure 8A,C). The thickness of these forms is usually less than $2 \mu \mathrm{m}$, and the length can be close to $1 \mathrm{~mm}$ (Figure 4 ). The bismuth drop diameter can be in large excess over the fiber thickness (Figure 5). Fibers of this type (especially at the early stage of growth) exhibit higher flexibility; their growth began the same as rods in the direction perpendicular to the substrate, and then fibers curve and set on greenockite rod aggregates of the first level (Figure 8A).

There are two extreme morphological types, which we conditionally called whiskers and wires. Whiskers are usually low curved and are more than $1 \mu \mathrm{m}$ in thickness and some hundreds of $\mu \mathrm{m}$ in length and exhibit a faceted side surface and hexagonal cross-section (Figure 11). Similar in morphology, thinner $\mathrm{CdS}$ whiskers were obtained in an experiment. They were studied under a transmission electron microscope, and it was established that the growth of these whiskers came in the [0001] direction $[5,6,20,26]$. Whiskers have a relatively big catalyst drop with an inhomogeneous surface (Figure 2B). The drop surface has cracks and is deformed (Figures 2B and 11-13). Radiating aggregates of rods of the second generation are noted on whiskers (Figures 8C, 10A,C,E and 12B).
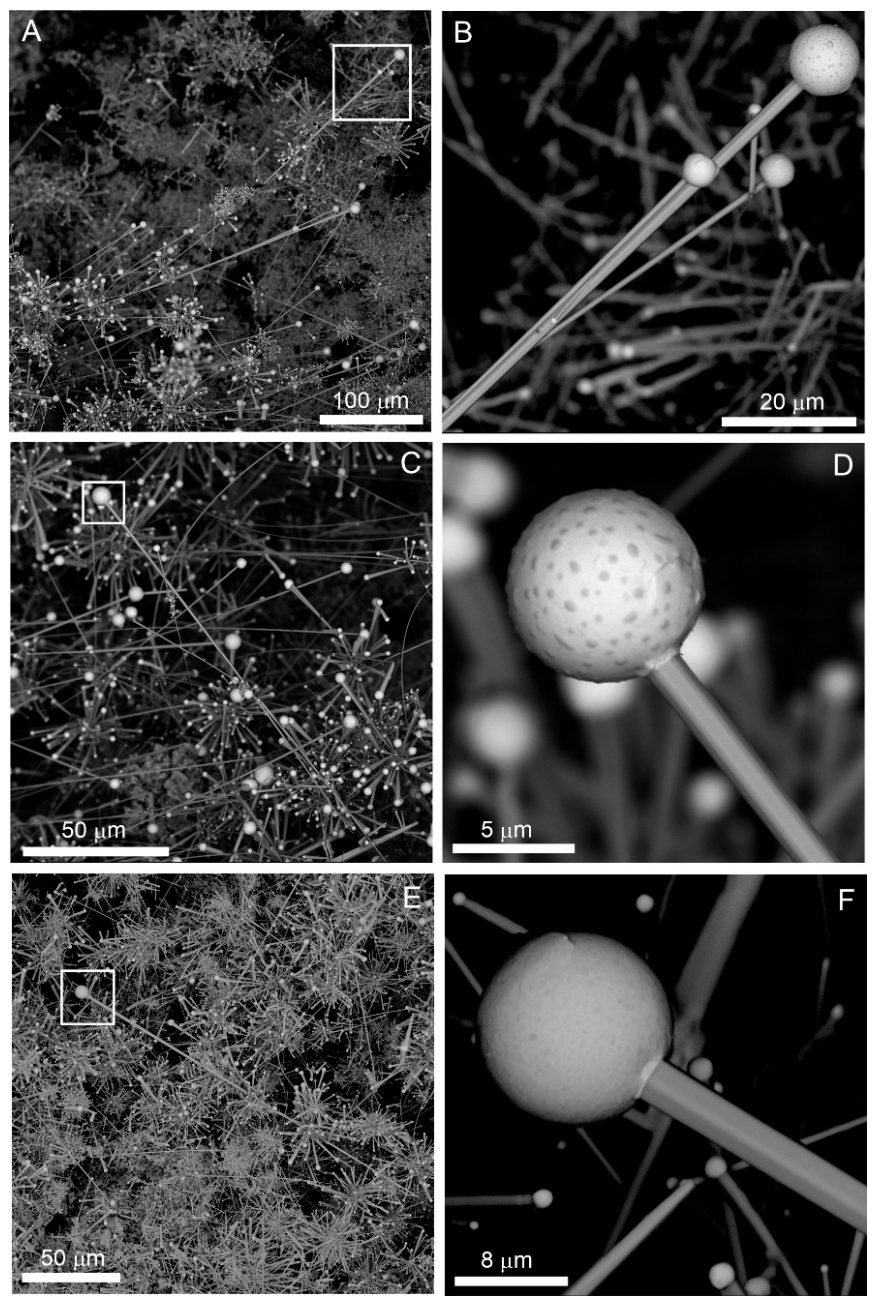

Figure 11. Straight-lined whisker with a big bismuth drop on the top, which has an inhomogeneous structure and cracks. (A,C,E) A common view, fragments magnified in the figures on the right side are outlined by frames; (B,D,F) Magnified fragments. Whiskers have hexagonal cross-sections and are elongated along [0001]. BSE images. 

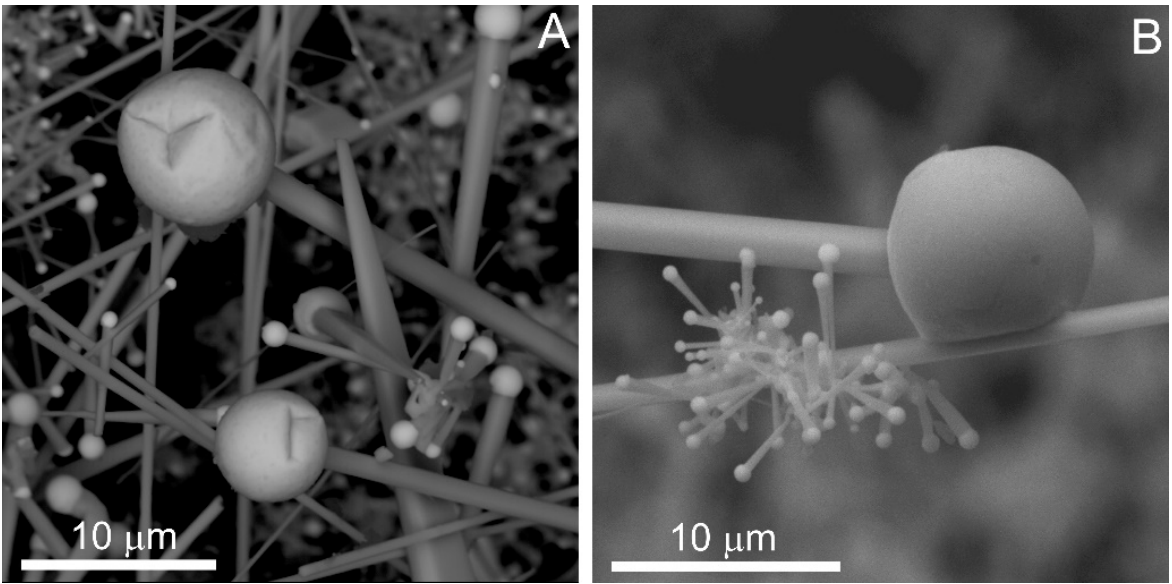

Figure 12. (A) Deformation of the catalyst drops with cracks and holes, BSE image. (B) Change of thte catalyst drop form on the wire obstacle, SE image.
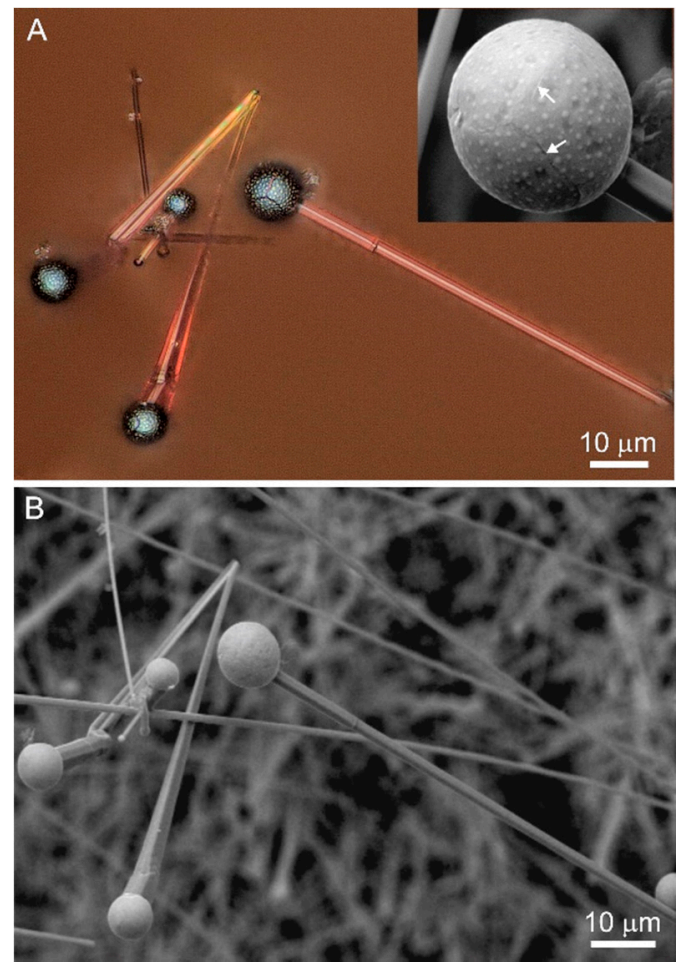

Figure 13. (A,B) Greenockite whisker with a catalyst drop having a shagreen surface and visible cracks (arrowed in the inset Figure 13A). (A) Optical image, in the inset, magnified drop on the crystal at the center of the image, BSE image. This whisker with a drop was later used in the experiment of the electron beam effect, see Figure 20F; (B) SE image.

Wires are nanoforms and have a diameter lesser than $1 \mu \mathrm{m}$ and several hundreds of $\mu \mathrm{m}$ in length, and, as well as whiskers, they are elongated on [0001] (Figure 14). This is confirmed by rare findings of wires with facetted top forms of the hexagonal cross-section (Figure 15). Wires are easily curved and interlaced. The catalyst drop diameter on the tops of these wires often exceeds their thickness by 5-6 times. Wires have a rounded cross-section and are often linked to each other by perpendicular rods through a common catalyst drop (Figure 14B,D,F). Figure 16 demonstrates a rare case when the wires are [01-10] oriented after kinking from the original [0001] growth direction. The different growth directions cause changes of the morphological type from wires to rods and this kinking is synchronic 
in neighboring wires. It is a known phenomenon in nanotechnology and the change of the growth direction occurs towards the higher temperature area $[27,28]$.
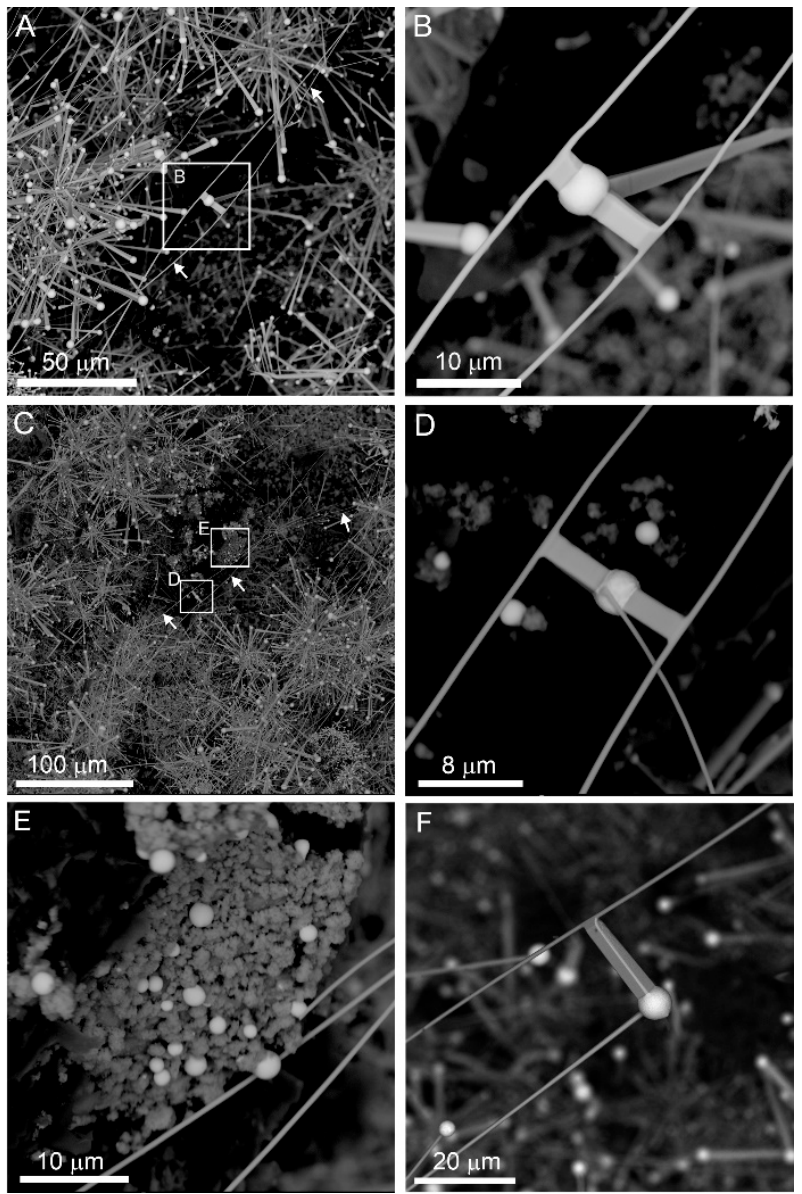

Figure 14. Wire nanometric greenockite forms elongated on [0001] with additional rod forms oriented perpendicular to wires (growth along [01-10]). (A,C) General view, nanowires are shown by arrows, magnified fragments, shown in Figure 13B,D,E, are outlined by frames; (B,D) Junction of two wires through rods having a common bismuth drop; (E) individual bismuth drops on aggregate enriched in hematite; (F) Common bismuth drop for wire and rod greenockite crystals.
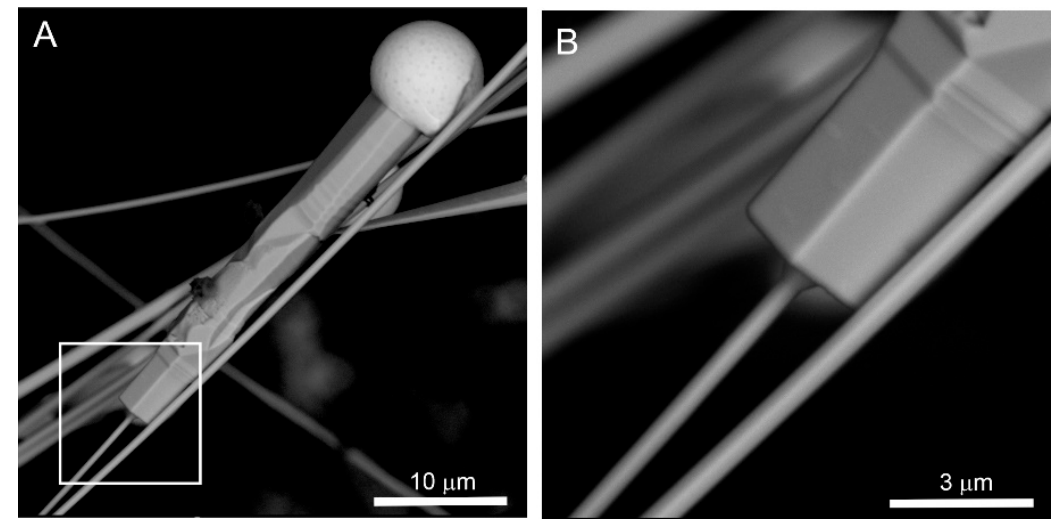

Figure 15. (A) A rare case of hexagonal crystal growth on greenockite wire; the fragment magnified in Figure 15B is outlined by frame; (B) Contact between the wire of the rounded cross-section and epitaxial prismatic crystal, which exhibits, besides a hexagonal prism, pyramid faces as well. 


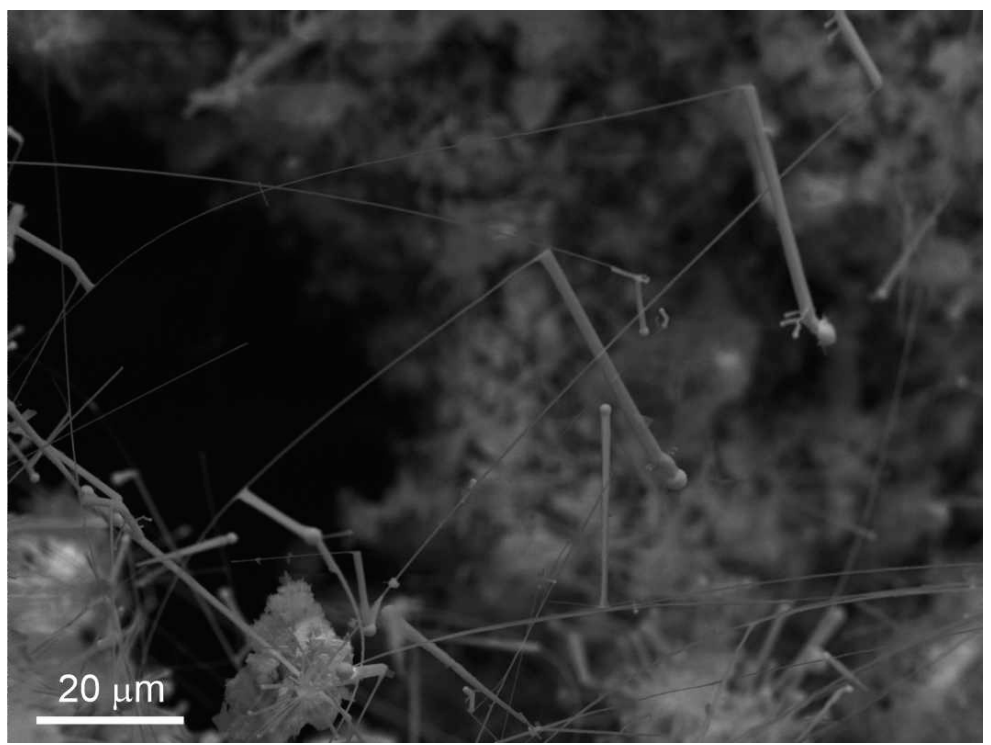

Figure 16. Kinking wires, direction growth change of axial wires from [0001] to [01-10] with simultaneous morphology change (wire-rod) responding to the effect of a drop falling off from the crystal top.

In a few cases, whiskers-wires were found, on which the thinnest plate hexagonal greenockite crystals overgrew (Figure 17).
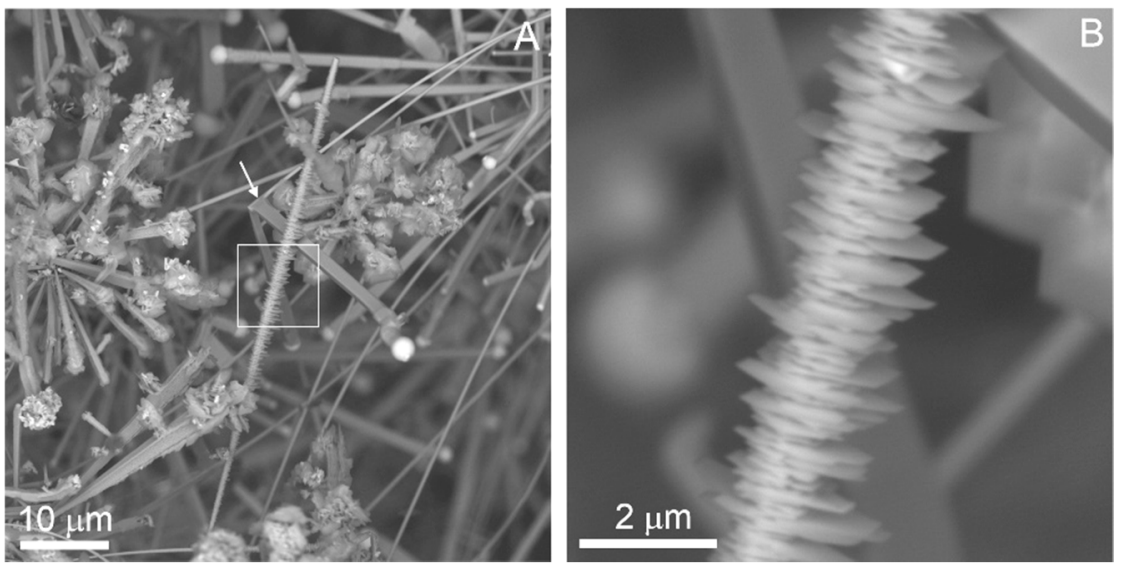

Figure 17. (A) Overgrowing of whiskers by plate hexagonal greenockite crystals. The arrow shows wire with synchronic flattened rods growing at an angle of $60^{\circ}$. The fragment magnified in Figure 17B is marked by frame; (B) series of hexagonal greenockite nanocrystals on the whisker. BSE images.

The composition of whiskers and wires was studied using SEM equipped with EDS. The composition of rods with bismuth drops was measured using a microprobe analyzer in polished mounts. Greenockite rods show a relatively stable composition (Table 1) with impurities of Se (up to 4.11 wt.\%), $\mathrm{Zn}$ (up to 0.67 wt.\%), $\mathrm{Pb}$ (up to $1.47 \mathrm{wt} \% \%$ ), and $\mathrm{Bi}$ (up to $1.63 \mathrm{wt. \%}$ ). In one of the analyses of the greenockite rod, the Bi content reaches $8.9 \mathrm{wt}$ \% (Table 1, analysis 9). Sb impurity is detected in two analyses (Table 1, analyses 7 and 9). 
Table 1. Microprobe data of the chemical composition of rod-like crystals of greenockite, wt.\%.

\begin{tabular}{|c|c|c|c|c|c|c|c|c|c|}
\hline Constituent & 1 & 2 & 3 & 4 & 5 & 6 & 7 & 8 & 9 \\
\hline $\mathrm{Cd}$ & 73.17 & 73.28 & 74.92 & 74.51 & 73.79 & 73.16 & 72.45 & 72.68 & 65.51 \\
\hline $\mathrm{Bi}$ & 0.15 & 0.15 & 0.17 & 0.51 & 0.63 & 0.86 & 1.40 & 1.63 & 8.93 \\
\hline $\mathrm{Zn}$ & 0.40 & 0.61 & 0.19 & 0.12 & 0.29 & 0.57 & 0.37 & 0.24 & 0.67 \\
\hline $\mathrm{Pb}$ & 0.48 & 0.46 & 0.23 & 0.12 & 0.11 & 0.36 & 1.10 & 0.16 & 1.47 \\
\hline $\mathrm{Sb}$ & n.d. & n.d. & n.d. & n.d. & n.d. & n.d. & 0.27 & n.d. & 0.60 \\
\hline$S$ & 19.32 & 19.86 & 20.14 & 20.27 & 20.18 & 19.80 & 19.54 & 19.41 & 17.38 \\
\hline Se & 4.11 & 3.03 & 2.84 & 2.13 & 2.05 & 3.06 & 2.91 & 3.38 & 3.45 \\
\hline Total & 97.62 & 97.38 & 98.49 & 97.67 & 97.05 & 97.80 & 98.05 & 97.50 & 98.01 \\
\hline \multicolumn{10}{|c|}{ Calculated on 2 atoms } \\
\hline $\mathrm{Cd}$ & 0.99 & 0.99 & 1.00 & 1.00 & 0.99 & 0.98 & 0.98 & 0.99 & 0.94 \\
\hline $\mathrm{Bi}$ & & & & & & 0.01 & 0.01 & 0.01 & 0.07 \\
\hline $\mathrm{Zn}$ & 0.01 & 0.01 & & & 0.01 & 0.01 & 0.01 & 0.01 & 0.02 \\
\hline $\mathrm{Pb}$ & & & & & & & 0.01 & & 0.01 \\
\hline $\mathrm{Sb}$ & & & & & & & & & 0.01 \\
\hline$S$ & 0.92 & 0.94 & 0.94 & 0.95 & 0.95 & 0.93 & 0.93 & 0.93 & 0.88 \\
\hline Se & 0.08 & 0.06 & 0.06 & 0.04 & 0.04 & 0.06 & 0.06 & 0.07 & 0.07 \\
\hline
\end{tabular}

Generally, the following regularities are noted according to EDS data:

(1) Idiomorphic and splitting greenockite crystals (Figure 7B,C) show a composition close to ideal: $\mathrm{Cd}\left(\mathrm{S}_{0.99} \mathrm{Se}_{0.01}\right)$.

(2) Non-stationary short-prismatic forms with bismuth drops on the top (Figures 6B and 7A) are greater than other types enriched in $\mathrm{Se}-\mathrm{Cd}\left(\mathrm{S}_{0.88} \mathrm{Se}_{0.12}\right)$.

(3) Well-shaped rods (Figure 9) show the following average composition: $\mathrm{Cd}\left(\mathrm{S}_{0.97} \mathrm{Se}_{0.03}\right)$.

(4) Whiskers (Figure 11) correspond to the average composition $\mathrm{Cd}\left(\mathrm{S}_{0.95} \mathrm{Se}_{0.05}\right)$ and small Bi impurities are detected within.

(5) Wires (Figure 14) show an average composition $\sim \mathrm{Cd}\left(\mathrm{S}_{0.93} \mathrm{Se}_{0.07}\right)$, and flattened rods on them are close by composition to $\sim \mathrm{Cd}\left(\mathrm{S}_{0.94} \mathrm{~S}_{0.06}\right)$.

The Raman spectrum was measured on rod greenockite crystal (Figure 18). The character of the Raman spectrum of CdS is strongly dependent on the grain size, its thickness, and crystallization degree [29]. The spectrum shape in the TO-LO range $\left(600-290 \mathrm{~cm}^{-1}\right)$ of the "bulk" structure and microcrystals differ significantly in the frequency of bands [30-32]. Due to this, we can conclude that our spectrum was performed on a microsize crystal of the hexagonal system [31,32]. The band at $294 \mathrm{~cm}^{-1}$ corresponds to LO A $A_{1}$ and LO E $E_{1}$ vibrations, and the band at $591 \mathrm{~cm}^{-1}$ is related to their first overtones [29,31-34]. The band at $255 \mathrm{~cm}^{-1}$ is attributed to $E_{2}$ vibration, which does not change the frequency depending on the studied crystal size. A weak band at $164 \mathrm{~cm}^{-1}$ can be attributed to the vibration of sulfur [35]. Some authors attribute bands at low frequencies to acoustic vibrations $[34,36]$.

To confirm the structure of the studied crystals, an X-ray powder diffraction analysis was performed (Figure 19). The sample contained greenockite (26.3\%), quartz (36.9\%), and minor amounts of the next minerals: Hematite, sanidine, epsomite, and anhydrite. Powder XRD studies confirm a hexagonal structure of greenockite. The obtained unit cell parameters present as follows: $a=4.13538$ (4) $\AA$, $\mathrm{b}=4.13538$ (4) $\AA, \mathrm{c}=6.71298$ (6) $\AA, \alpha=90^{\circ}, \beta=90^{\circ}, \gamma=120^{\circ}$, and they are slightly bigger than those given in the literature [37]. 


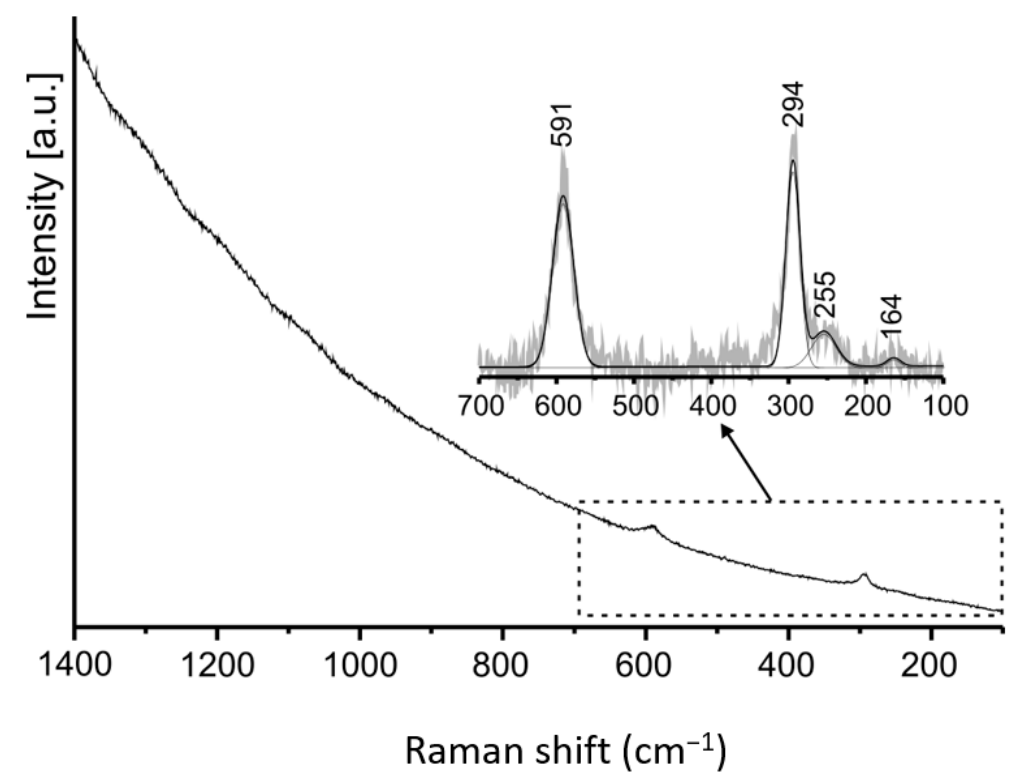

Figure 18. Raman spectrum of greenockite.
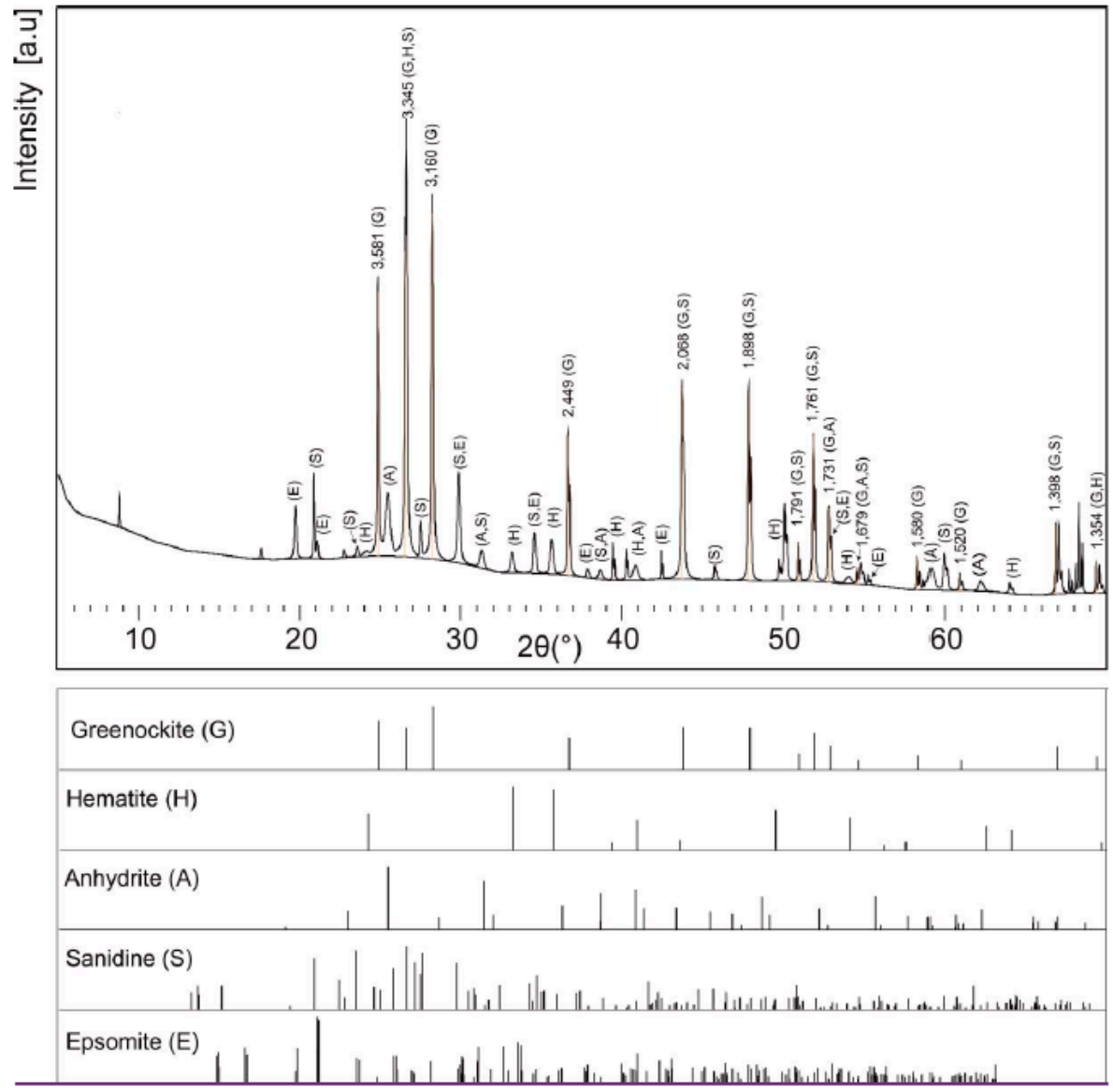

Figure 19. X-ray powder diffraction pattern of orange crust. Labels of minerals and $d_{h k l}(\AA)$ of greenockite are shown in the pattern. 
Bismuth drops on whiskers have a "knobby" shagreen surface and inhomogeneous composition. In some spots, these "knobbles" are enriched in S and Cd (Figure 11D), and rarely in $\mathrm{Pb}, \mathrm{Sb}$, and $\mathrm{As}$. We did not detect tellurium, described earlier in bismuth drops on greenockite crystals from coal dumps in the Czech Republic [12-14]. We were unable to obtain more precise data on the composition of the drop surface because of their small size. The drops were destroyed as a result of our attempts to perform elemental $\mathrm{X}$-ray mapping (see explanation below).

The chemical composition of relatively big catalyst drops on rods composed of metal bismuth is characterized by a considerable variation of impurities (Table 2, wt.\%): Cd 1.25-11.05; Pb 0-15.42; Sb 2.83-6.50; and S 0.98-2.90.

Table 2. Chemical composition of Bi drops on the rod crystal tops.

\begin{tabular}{ccccc}
\hline Constituent & $\mathbf{1}$ & $\mathbf{2}$ & $\mathbf{3}$ & $\mathbf{4}$ \\
\hline $\mathrm{Bi}$ & 81.81 & 86.51 & 84.07 & 78.05 \\
$\mathrm{Cd}$ & 11.05 & 3.16 & 5.57 & 1.25 \\
$\mathrm{Zn}$ & 0.16 & 0.19 & 0.07 & 0.03 \\
$\mathrm{~Pb}$ & n.d. & 0.70 & 2.13 & 15.42 \\
$\mathrm{Sb}$ & 4.74 & 6.50 & 2.83 & 4.91 \\
$\mathrm{~S}$ & 2.90 & 0.98 & 1.38 & 0.38 \\
$\mathrm{Se}$ & 0.27 & 0.02 & 0.24 & n.d. \\
$\mathrm{Total}$ & 100.94 & 98.06 & 96.29 & 100.02 \\
$\mathrm{C}$ & \multicolumn{2}{c}{ Calculated on 1 atom } \\
$\mathrm{Cd}$ & 0.16 & 0.05 & 0.09 & 0.02 \\
$\mathrm{Bi}$ & 0.63 & 0.78 & 0.76 & 0.73 \\
$\mathrm{Zn}$ & \multicolumn{5}{c}{0.01} & 0.15 \\
$\mathrm{~Pb}$ & 0.06 & 0.01 & 0.02 & 0.08 \\
$\mathrm{Sb}$ & 0.14 & 0.10 & 0.04 & 0.02 \\
$\mathrm{~S}$ & 0.01 & 0.08 & \\
$\mathrm{Se}$ & & & 0.01 & \\
\hline
\end{tabular}

ICP-MS analyses of the crystal aggregate (B1) and substrate (B2) were performed (Table 3). Probe B1 in comparison with probe B2 is characterized by enrichment in the following elements: Cd, Se, $\mathrm{Bi}, \mathrm{Pb}, \mathrm{As}$, and $\mathrm{Te}$, and depletion in $\mathrm{Ba}, \mathrm{Mg}, \mathrm{Al}, \mathrm{Ca}, \mathrm{Mo}, \mathrm{Fe}$, and $\mathrm{Cu}$. The sulfur content in both probes is similar. The ICP-MS results were compared with data given in the literature for coal from the northern part of the Upper Silesian Coal Basin; these data are presented in Table 3. We cannot compare the contents of all elements, given for our analyses, because the literature data is represented by a limited number of measured elements. High contents of elements in the analyses performed for our probes are bolded in Table 3.

Table 3. ICP-MS data obtained for greenockite aggregate (B1), the substrate (B2), and literature data (3) for hard coal of the Upper Silesian Coal Basin [38], ppm.

\begin{tabular}{|c|c|c|c|c|c|c|c|}
\hline Constituent & B1 & B2 & 3 & & B1 & B2 & 3 \\
\hline Mo & 0.12 & 0.59 & & $\mathrm{Na}$ & 160 & 120 & \\
\hline $\mathrm{Cu}$ & 36.1 & 68.21 & 17.47 & $\mathrm{~K}$ & 1900 & 2200 & \\
\hline $\mathrm{Pb}$ & 101.76 & 36.77 & 22.34 & W & $<0.1$ & $<0.1$ & \\
\hline $\mathrm{Zn}$ & 86.7 & 112.5 & 89.47 & $\mathrm{Sc}$ & 3.4 & 4.1 & \\
\hline $\mathrm{Ag}$ & 0.077 & 0.088 & & $\mathrm{Tl}$ & 0.11 & 0.11 & \\
\hline $\mathrm{Ni}$ & 10.6 & 15.4 & 12.15 & $\mathrm{~S}$ & 1600 & 1500 & \\
\hline Co & 4.5 & 6.6 & 5.44 & $\mathrm{Hg}$ & 0.0044 & $<0.0005$ & 0.02 \\
\hline $\mathrm{Mn}$ & 83 & 128 & 119.89 & Se & 63.2 & 3.3 & \\
\hline $\mathrm{Fe}$ & 4300 & 7900 & & $\mathrm{Te}$ & 1.48 & 0.09 & \\
\hline As & 3.5 & 1.2 & 3.44 & $\mathrm{Ga}$ & 2.6 & 4 & \\
\hline $\mathrm{U}$ & 1.1 & 1.2 & & Cs & 4.35 & 3.71 & \\
\hline
\end{tabular}


Table 3. Cont.

\begin{tabular}{|c|c|c|c|c|c|c|c|}
\hline Constituent & B1 & B2 & 3 & & B1 & B2 & 3 \\
\hline $\mathrm{Au}$ & 0.0009 & $<0.0002$ & & $\mathrm{Ge}$ & $<0.1$ & $<0.1$ & \\
\hline Th & 4.7 & 4.5 & & $\mathrm{Hf}$ & 0.3 & 0.26 & \\
\hline $\mathrm{Sr}$ & 48.4 & 47.2 & 121.51 & $\mathrm{Nb}$ & 0.24 & 0.15 & \\
\hline $\mathrm{Cd}$ & 1433.62 & 57.6 & 0.83 & $\mathrm{Rb}$ & 18.7 & 18.7 & 8.05 \\
\hline $\mathrm{Sb}$ & 6.43 & 2.53 & 1.23 & Sn & 2.1 & 1.3 & \\
\hline $\mathrm{Bi}$ & 138.37 & 10.63 & & $\mathrm{Ta}$ & $<0.05$ & $<0.05$ & \\
\hline $\mathrm{V}$ & 56 & 74 & 25.24 & $\mathrm{Zr}$ & 9.5 & 7.2 & \\
\hline $\mathrm{Ca}$ & 1400 & 2200 & & $\mathrm{Y}$ & 2.85 & 2.52 & \\
\hline $\mathrm{P}$ & 100 & 120 & & $\mathrm{Ce}$ & 31.8 & 27.5 & \\
\hline $\mathrm{La}$ & 15.7 & 13.1 & & In & 0.63 & 0.07 & \\
\hline $\mathrm{Cr}$ & 23.9 & 27.4 & 10.73 & $\operatorname{Re}$ & 0.0001 & $<0.0001$ & \\
\hline $\mathrm{Mg}$ & 1400 & 2300 & & $\mathrm{Be}$ & 0.5 & 0.8 & \\
\hline $\mathrm{Ba}$ & 48.8 & 67.5 & 142.66 & $\mathrm{Li}$ & 9.6 & 13.8 & \\
\hline $\mathrm{Ti}$ & 130 & 130 & & $\mathrm{Pd}$ & * & $<0.01$ & \\
\hline B & $<20$ & $<20$ & & $\mathrm{Pt}$ & $<0.02$ & $<0.02$ & \\
\hline $\mathrm{Al}$ & 7300 & 10200 & & & & & \\
\hline
\end{tabular}

Anomalous high contents of elements are bolded.

\section{Catalyst Drop Behavior under Electron Beam Affect}

Catalyst drops, being on the tops of thin whiskers (drop diameter to whisker thickness ratio > 5), began to change their form dynamically (bulges appear in different areas of drop) and exploded with spraying bismuth (which decorates whisker top) under the electron beam effect, which had some higher parameters in comparison to the standard conditions in an SEM chamber (an insignificant increase of spot and/or accelerating voltage) (Figure 20). The two-second effect by the electron beam of $25 \mathrm{kV}$ on the catalyst drop (Figure 20A) led to change of its surface, which was reflected in the appearance of lighter spots, represented by practically pure bismuth, and grey spots enriched in $\mathrm{Cd}$ and S (Figure 20B). Besides, on the top of the whisker in contact with the Bi drop, a thin film of bismuth is observed (Figure 20B). the continued effect by the beam during five seconds led to an explosion of the drop and covering by bismuth near the top part of the whisker and neighboring greenockite crystal (Figure 20C). The drop shell convolved around the crystal but did not melt down.

We repeated a similar experiment on the next few crystals and received an effect of a "deflated balloon" hanging on the whisker top covered by a new-formed nano-film of bismuth for the length of 10-20 $\mu \mathrm{m}$ (Figure 20D-F). It is interesting that the whisker, having a visible crack on the drop surface, shown in Figure 13A, also exploded, sputtering both relatively big bismuth drops up to $1 \mu \mathrm{m}$ in size, and nanometric drops, which decorated the surrounding crystals (Figure 20F). If the exploded drop is close to the facceted greenockite crystal, then crystal will be decorated by small drops along on the edges, this phenomenon is called as the "Lemmlein's dew effect" (Figure 21A) [39]. Interestingly, this similar decoration by nano-drops took place during greenockite fibers' growth, which was accompanied by nano-fiber formation (Figure 21B).

The description above indicates that the catalyst drop has a complex structure. It has a metal shell composed of bismuth, which is a few hundred nm thick, and its internal part is filled in substance with a relatively low melting temperature with respect to the bismuth shell.

We were able to receive an image of the drop before its explosion (Figure 22). The drop sharply increases its volume to $15-20 \%$, which was connected with gas emission from the liquid phase inside the drop. In one case, during the electron beam's influence on the catalyst drop, it exploded and a dark phase remained (shown in the BSE image, Figure 23) with a high carbon content at the internal side of the drop shell. 

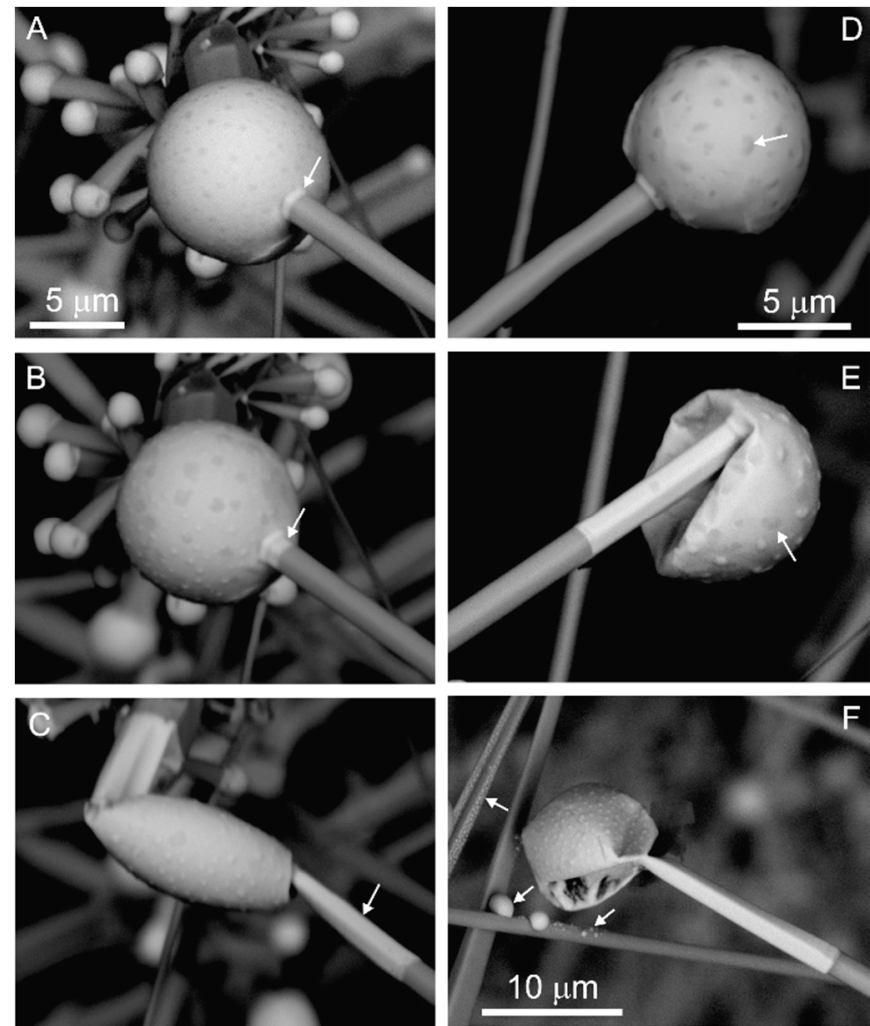

Figure 20. The behavior of catalyst drops under an electron beam. (A-C): (A) Character of the catalyst drop under the standard electron beam condition ( $15 \mathrm{kV}$ and vacuum $10^{-7}$ Torr); bismuth coat at the whisker top, which possibly appeared after its formation (arrow). (B) After a two-second influence on the catalyst drop by an electron beam of $25 \mathrm{kV}$. At the top of the whisker, a surface of the Bi coat increased (the arrow); on the drop surface, grey spots enriched in S and Cd became larger. (C) After $5 \mathrm{~s}$ of being affected by a beam of $25 \mathrm{kV}$, a catalyst drop exploded, and bismuth covered the whisker (the arrow) and the neighboring prismatic crystal, which was above the whisker. (D,E) Drop before the $25-\mathrm{kV}$ beam effect. The arrows show the same object in both images. Whisker top was covered by bismuth film. (F) Change of the catalyst drop shape with cracks on the surface under $25 \mathrm{kV}$ electron beam of the crystal shown in Figure 13A. After the explosion of the catalyst drop whisker, the top was covered by bismuth film on the distance of $18 \mu \mathrm{m}$, small bismuth drops fallen irregularly on the wire, and the decorated surface of facetted greenockite whisker (arrows).
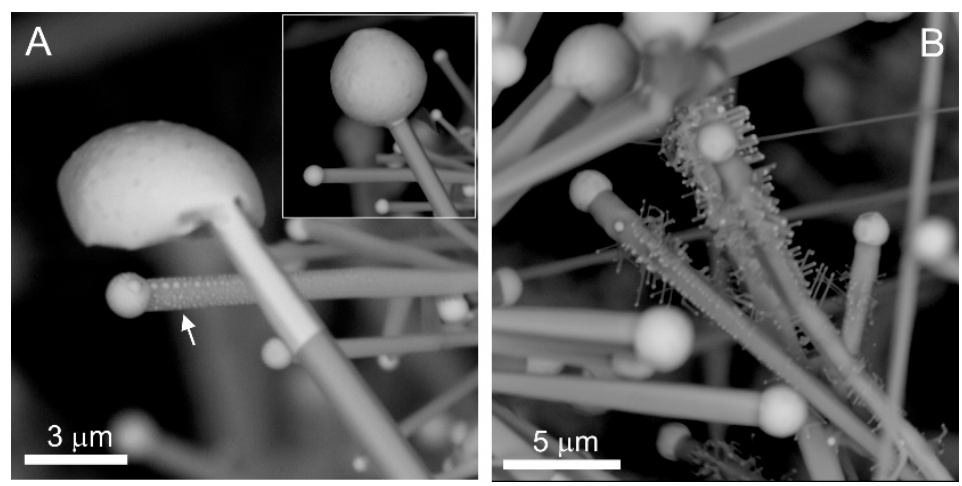

Figure 21. (A) Decoration of rod edges by bismuth nano-drops (the arrow) being close to the exploded catalyst drop, which was affected by increased beam spot at $15 \mathrm{kV}$ (Phenom XL); in the inset-drop before the experiment. (B) Rods with bismuth droplet decoration and very thin fibers growing due to these drops. 

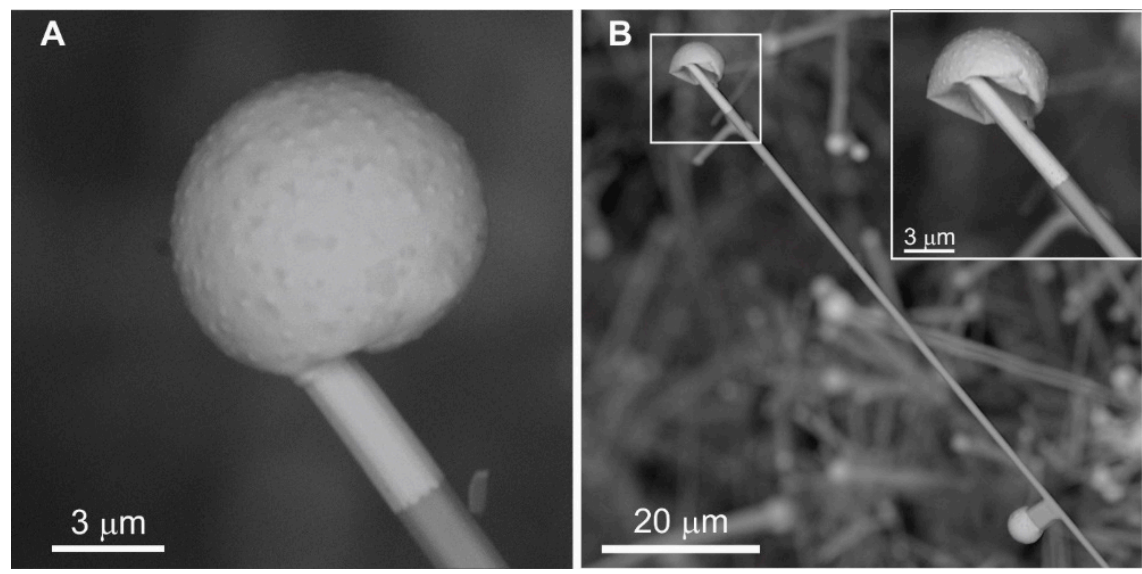

Figure 22. (A) Rare case, inflated catalyst drop increases to $15-20 \%$ of its original volume, from which bismuth felt out and covered a top of whisker for the length of $6 \mu \mathrm{m}$. (B) The same crystal after the drop explosion (frame and in the inset). Bismuth film covers whisker for the length of $20 \mu \mathrm{m}$. Catalyst drop on the rod branch of a whisker does not change at the same conditions (on the bottom of the image).

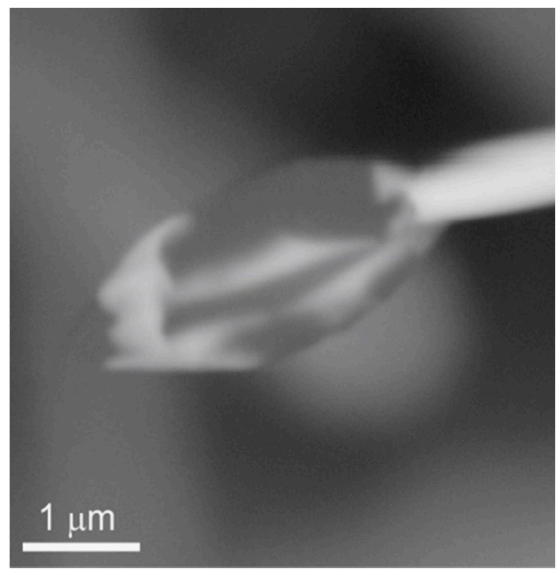

Figure 23. Exploded drop with carbonaceous substance (dark) inside.

We also checked the behavior of a relatively homogenous Bi catalyst drop on short rod crystal under an $25 \mathrm{kV}$ electron beam. We were not able to melt this drop, and only grey fragments enriched in sulfur and cadmium appeared on its surface (Figure 24).
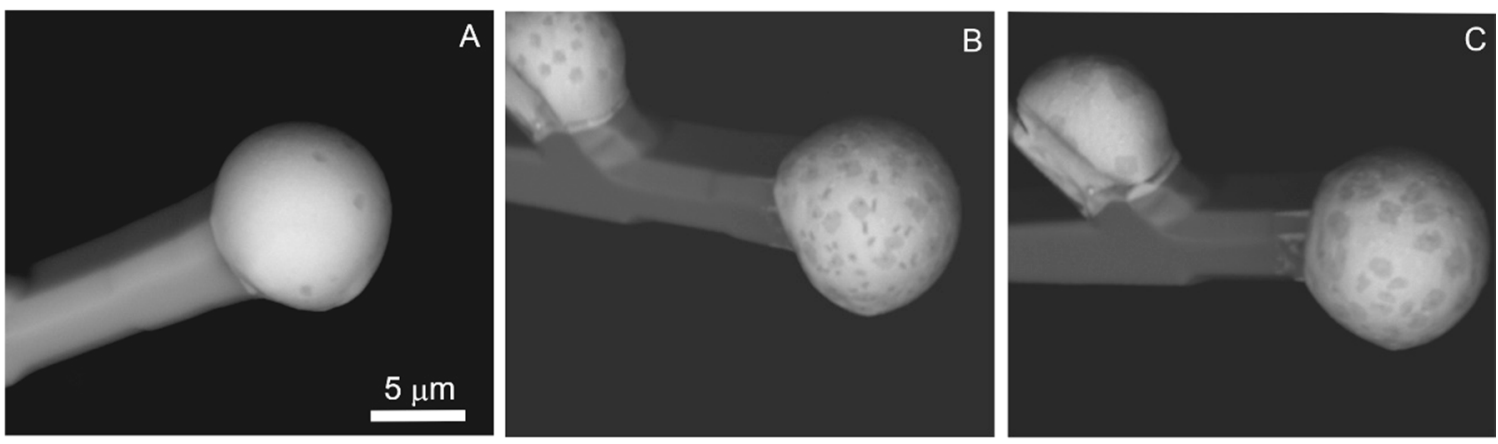

Figure 24. Catalyst drop behavior on the top of rod crystal under a $25 \mathrm{kV}$ electron beam: (A) original crystal; (B) after $5 \mathrm{~s}$ of the effect; (C) after $25 \mathrm{sec}$ of the effect. Crystal during the experiment changed its position in space. 


\section{Discussion}

Greenockite has specific pyramidal crystals (Figure 7B) reflecting the character of its polar structure (absent of center of inversion, [40,41]). Greenockite crystals differ by the pedion faces' character: $(0001)$ has common edges with the hexagonal pyramid and small square (down to wedge-shaped crystal), it is responding to the direction of the highest crystal growth rate, and its shape depends on this rate (Figure 7B) [6]; (000-1) is well developed on greenockite crystals, forms edges with the hexagonal prism, and is responding to the direction of slower crystal growth in comparison with the opposite direction. Thus, the most favorable growth direction of filamentous and needle-like forms of greenockite is [0001].

All morphological types of greenockite from Bytom formed within a short period when fumarole was active. At the beginning of the fumarole activity at $500-600{ }^{\circ} \mathrm{C}$, nano- and microcrystals of greenockite formed from gas. As a result of the temperature reduction, drops of liquid bismuth formed on the burned-out substrate (Figure 14A). The contact of these drops with previously formed greenockite crystals may arise in conditions for the initiation of the VLS mechanism. Rods grow along the [01-10] direction, their length usually does not exceed several dozen microns (Figure 4), and they form the first level of the orange greenockite crust (Figure 8A). Whiskers and wires (axial forms) grow along the [0001] direction, which is determined on its morphology (Figures 11 and 15). Their length may approach $1 \mathrm{~mm}$ and their thickness is 100 times smaller than the length (Figures 4, 8 and 14). They are usually placed sub-parallel to the substrate and lie on the radiating aggregate of rod crystals forming a specific second level (Figures 2 and 8A,C). Greenockite whisker and wire growth began growth perpendicular to the substrate as well as rods, but due to the catalyst drop weight, the heat transfer direction, and their high flexibility they curve and lie sub-parallel to the substrate surface (Figures 2 and $8 \mathrm{~A}$ ). There are two types of fiber axial forms: facetted linear whiskers several dozen hundred $\mu \mathrm{m}$ in length and few $\mu \mathrm{m}$ in thickness, and wires-more than $100 \mu \mathrm{m}$ in length and less than $0.5 \mu \mathrm{m}$ in thickness (Figures 11 and 14). Whiskers possess \{01-10\} hexagonal prism faces, whereas nanowires exhibit rounded surface (Figures 11F, 14B and 15B). Perpendicular flattened branches elongated on [01-10] are noted on wires (Figure 14B,D,F), the morphology of these branches corresponds to the rod morphology (Figure 9). If our proposition as to orientation is right, then rods exhibit faces close to the plane of second hexagonal prism $\{-12-10\}$ and pedion faces (0001) and (000-1). In Figure 10D it is well visible how parallel branches of the second generation of greenockite are growing on the "mother rod": quick growth of the thin crystal in the direction [0001] and slow in the direction [000,1]. Also, the possibility cannot be excluded that some rods grow in the direction perpendicular to faces of the second hexagonal prism [-12-10] (i.e., growth by micro-face-edges of $\{01-10\}$ prism), then in faceting of rods, two parallel faces of hexagonal prism $\{01-10\}$ and monoedrs (0001) and (000-1) will take part. Edges between the base faces of rods with rectangular cross-section are complicated by appearing of pyramid faces, which leads to the octagonal form cross-section (Figures 9 and 10F).

Position of different morphological types of greenockite fibers and rods in aggregates indicated their simultaneous growth: the relatively short crystal formed on [01-10], and whiskers and nanowires-on [0001]. Formation of fiber crystals was connected with the period of fumarole activity at relatively stable conditions, which nevertheless can be locally changed, for example, by a sudden gust of wind, appearance of the new gaseous channel, and so on. So, the growth of flattened greenockite crystals on whisker, as crystals formed directly from the gas, and kinking of wires (Figures 16 and 17) are rather associated with local temperature increase $[27,28]$.

At the beginning of fumarole formation diverse small greenockite crystals, which worked as seeds (substrate) for fiber crystals, grew from gas. Interestingly, these bismuth drops, which hit to the substrate without greenockite crystals, did not generate greenockite fibers (Figure 14E). Fibers formed at temperatures lower than greenockite crystals forming from gas. The presence of bismuth drops on the tops of growing crystals points out its growth by the VLS mechanism. Bismuth drop diameter on rod tops is insignificantly larger than a crystal thickness (Figure 5) as it usually is at such mechanism $[3,4,19,20,42]$. We were not able to melt bismuth drops on rods under the $25 \mathrm{kV}$ electron beam (Figure 24). Catalyst drops on rods have an inhomogeneous composition with significant 
variations of $\mathrm{Cd}, \mathrm{Pb}, \mathrm{S}, \mathrm{Sb}$ impurities content (Table 2), which can decrease a melting point of eutectic mixture of metals [43]. We consider that rod growth occurred at a temperature higher than $270{ }^{\circ} \mathrm{C}$ (melting point of pure bismuth, [44]) in areas of hot gas efflux. Greenockite crystals, formed from the gaseous phase at temperatures of $500-600{ }^{\circ} \mathrm{C}$, close to the maximal measured at fire foci, are different due to the low Se content in comparison to crystals formed by the VLS mechanism. Together with rods, the relatively quick growth of whiskers and wires, for which the characteristic feature is the presence of a relatively big catalyst drop, occurred, the diameter of which exceeded the crystal thickness several times (Figure 5). Under the minor heating of the electron beam, the metallic Bi shell of the catalyst drop becomes elastic, and a filling substance transfers to the liquid state (probably together with the gas emission) (Figure 22). Whiskers and wires grow above the substrate (at the second level of the crust) at a relatively low temperature in the heterogeneous atmosphere of combustion products. Among the products, there are various chemical compounds, such as atoms and molecules of different gases, molecular complexes (possibly with organic components), and also nanodrops and nanoparticles, which transport both the $\mathrm{Cd}$ and $\mathrm{S}$ necessary for greenockite crystallization, and other chemical substances influenced the eutectic point of the catalyst mixture. Whiskers; and wires' growth is very fast $[3,4,6]$. It is limited in space only by a few-millimeter zone under the fumarole (gas channel), where there is no significant impact of the environment. Besides, kinetic factors [45] and cooperative effects influence the growth of individual fiber greenockite crystals.

Fiber crystals grow almost immediately above the substrate, sorbing gaseous components on the surface of the catalyst drop, which are necessary for crystal growth. Our experiments of heating catalyst drops on whisker tops allow the suggestion that the gas kept inside escapes during the experiment from the inside of the catalyst drop (Figures 20-23). This effect of an "air-balloon" sharply increases the active area of the catalyst drop and as a result, influences the growth rate of whiskers and wires. Part of the drops lost gas (possibly in the SEM chamber), which is reflected in the appearance of the catalyst drop form resembling a "rotten apple" (Figure 12A). Moreover, in the room conditions, the filling substances in catalyst drops are in the solid state as these drops can have cracks and preserve their shape (Figure 13A).

We consider that whiskers and wires formed at a lower temperature than rods, possibly even lower than $200{ }^{\circ} \mathrm{C}$. In this case, the growth mechanism of greenockite whiskers and wires was more complicated than the VLS mechanism and it was close to the mechanism of fiber crystal growth called the VQS mechanism in which the liquid phase has an inhomogeneous composition and contains solid particles (Q-quasi-liquid) [4,19]. In our case, a nanometric bismuth film of solid metal, which determined the shape stability of the catalyst, is formed on the liquid drop. By this layer, components of the whisker and wires are diffused to the drop-crystal interface. The droplet size is several times larger than the thickness of the whisker itself, which creates good conditions for surface diffusion (Figure 25) [4,19,20,46].

However, when wire growth sharply stopped, specific effects are observed. In Figure 26, cases of wire growth braking are schematically shown as a result of the cooperative phenomena. The formation of flattened branches on the side area of the growing crystal is caused by contact of the catalyst drop of one wire with the face of another greenockite wire (Figure 14B,D,F, and Figure 25), and the growth of the provider of the drop is completely stopped. Braking of the wire growth on allogeneic obstacles is a rare phenomenon; in this case, the thickening and formation of faces at the near-top part of the wire is observed (Figures 15 and 26III-b). 

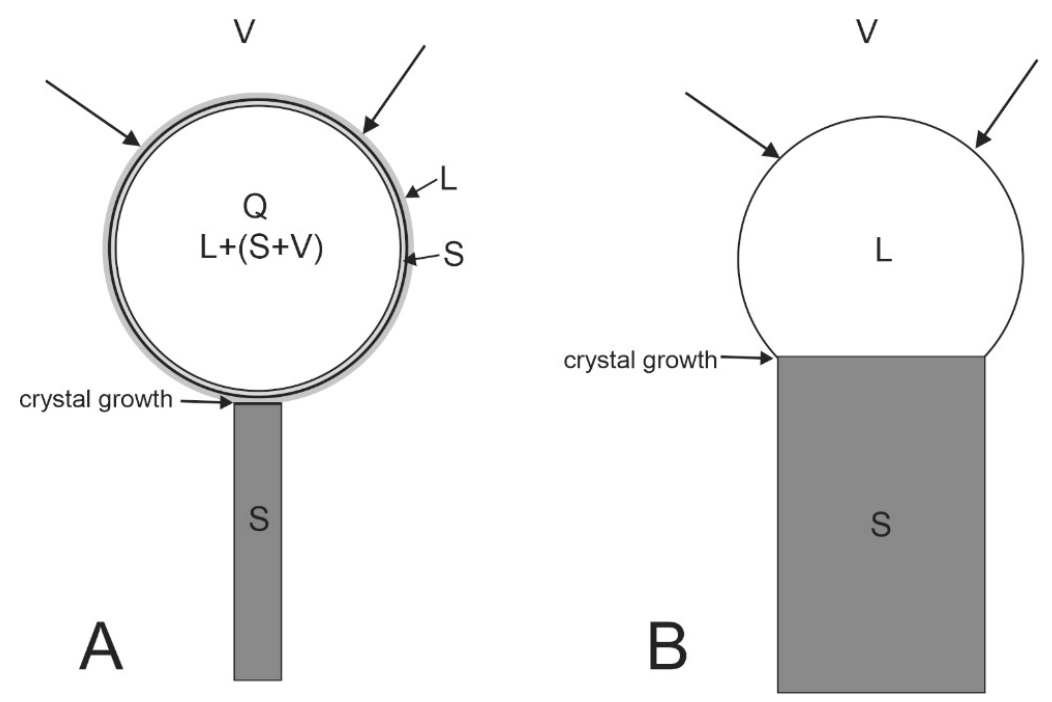

Figure 25. Sketch showing the VQS growth mechanism of greenockite wires and whiskers (A) and rods growth by the VLS mechanism (B); Q: quasi-liquid; S: solid; V: gas; L: liquid.
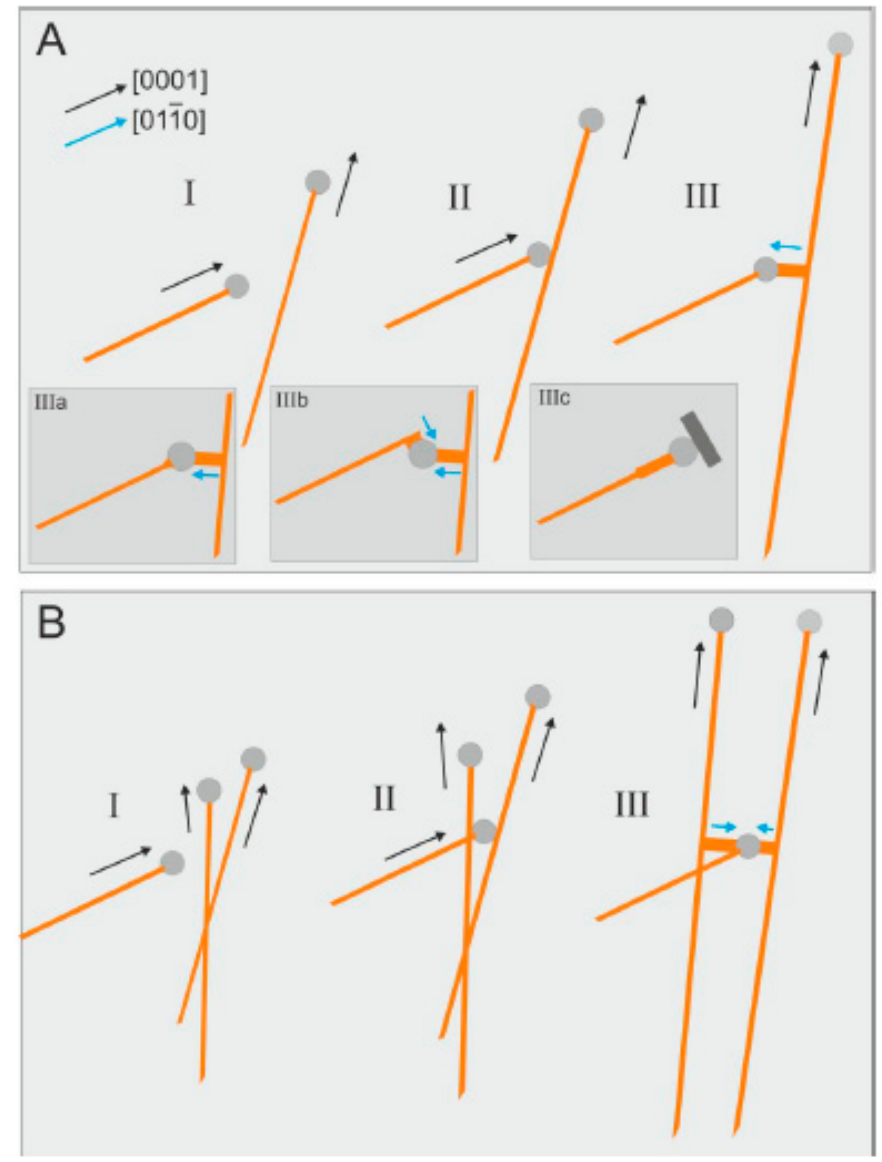

Figure 26. Sketch of cooperative phenomena at whisker growth. (A) Interaction of the catalyst drop of one wire crystal with the other wire: I-III: successive growth stages. III-a:formation of a flattened branch on the wire and the appearance of thickening on the braked whisker; III-b: falling of the catalyst drop from the braked wire top and the formation of flattened branches on both wires; IIIc-thickening of the braked whisker. (B) Interaction of the catalyst drop with two crystals and the formation of a flattened brigde between two growing whiskers: I-III: successive stages. 


\section{Conclusions}

For the first time, we showed that in nature, whiskers can form by the VQS crystal growth mechanism, more complicated than the known VLS mechanism. The evidence of whisker crystal growth by the VQS mechanism is the phase heterogeneity of the catalyst drop.

Greenockite crystals, the formation of which is connected with active fumaroles at burned coal dumps, are represented by diverse morphological forms corresponding to different temperatures and mechanisms of growth. Idiomorphic and splitting greenockite crystals formed at $500-600{ }^{\circ} \mathrm{C}$ from gas (Figure 7B,C). At temperatures close to the melting point of bismuth (not lower than $270{ }^{\circ} \mathrm{C}$ [44]), greenockite rod crystals, carrying on top a relatively homogenous bismuth catalyst drop, were formed on the heated substrate according to the VLS mechanism. Just above of the substrate surface at the temperature of $200{ }^{\circ} \mathrm{C}$ (probably lower, as $60 \% \mathrm{Bi}+40 \% \mathrm{Cd}$ eutectic mixture has a melting temperature of $146^{\circ} \mathrm{C}$ ) [47], greenockite whiskers and wires grew according to the VQS mechanism. The catalyst drop that had a complex structure was the metallic bismuth shell (during growth probably with the liquid nanometric film), which was filled by an inhomogeneous liquid substance, mainly containing bismuth. Possibly, Cd and Bi were transported by metal-organic complexes, the heating of which led to Bi shell formation on the catalyst drop and "inflation" of the drop by the release of gas.

Author Contributions: All authors took part in writing of paper; K.N. collected samples for investigation; K.N. investigated samples using SEM with help of I.G. and E.G.; K.N. prepared probes for powder X-ray diffraction study and performed interpretation, selected probe for ICP-MS analysis; K.N. and I.G. performed EPMA of greenockite and bismuth drops; E.G. measured Raman spectrum; K.N. and E.G. prepared figures for paper. All authors have read and agreed to the published version of the manuscript.

Funding: This research received no external funding.

Acknowledgments: K.N. thanks to Patryk Kosałka for help in sample collection. The authors thank to three anonymous reviewers and David French for comments allowed to improve the manuscript.

Conflicts of Interest: The authors declare no conflict of interests.

\section{References}

1. Pokropivny, V.V.; Skorokhod, V.V. Classification of nanostructures by dimensionality and concept of surface forms engineering in nanomaterial science. Mater. Sci. Eng. C 2007, 27, 990-993. [CrossRef]

2. Wagner, R.S.; Ellis, W.C. Vapor-Liquid-Solid mechanism of single crystal growth. Appl. Phys. Lett. 1964, 4, 89-90. [CrossRef]

3. Huang, X.; Wang, Z.-J.; Weinberg, G.; Meng, X.-M.; Willinger, M.-G. In Situ Scanning Electron Microscopy Observation of Growth Kinetics and Catalyst Splitting in Vapor-Liquid-Solid Growth of Nanowires. Adv. Funct. Mater. 2015, 25, 5979-5987. [CrossRef]

4. Wang, N.; Cai, Y.; Zhang, R.Q. Growth of nanowires. Mater. Sci. Eng. R Rep. 2008, 60, 1-51. [CrossRef]

5. Grynko, D.A.; Fedoryak, A.N.; Dimitriev, O.P.; Lin, A.; Laghumavarapu, R.B.; Huffaker, D.L. Growth of CdS nanowire crystals: Vapor-liquid-solid versus vapor-solid mechanisms. Surf. Coat. Technol. 2013, 230, 234-238. [CrossRef]

6. Zhang, J.; Yang, Y.; Jiang, F.; Li, J.; Xu, B.; Wang, S.; Wang, X. Fabrication of semiconductor CdS hierarchical nanostructures. J. Cryst. Growth 2006, 293, 236-241. [CrossRef]

7. Dong, L.; Jiao, J.; Coulter, M.; Love, L. Catalytic growth of CdS nanobelts and nanowires on tungsten substrates. Chem. Phys. Lett. 2003, 376, 653-658. [CrossRef]

8. Dymkov, Y.M. Paragenesis of Uran-Bearing Vein Minerals; Nedra: Moscow, Russia, 1985.

9. Novgorodova, M.I.; Boyarskaya, R.V.; Yusupov, R.G. Growth and corrosion of native zinc in gaseous medium. Proc. Russ. Mineral. Soc. 1986, 115, 16-25. [CrossRef]

10. Finkelman, R.B.; Larson, R.R.; Dwornik, E.J. Naturally occurring vapor-liquid-solid (VLS) Whisker growth of germanium sulfide. J. Cryst. Growth 1974, 22, 159-160. [CrossRef]

11. Lapham, D.M.; Barnes, J.H.; Downey, W.F., Jr.; Finkelman, R.B. Mineralogy Associated with Burning Anthracite Deposits of Eastern Pennsylvania; Mineral Resource Report; Pennsylvania Geological Survey: Harrisburg, PA, USA, 1980; Volume 78. 
12. Žaček, V.; Ondruš, P. Mineralogy of recently formed sublimates from Katerina colliery in Radvanice, Eastern Bohemia, Czech Republic. Věstnik Čes. Geol. Úst. 1997, 72, 289-302.

13. Witzke, T.; de Wit, F.; Kolitsch, U.; Blaß, G. Mineralogy of the Burning Anna I Coal Mine Dump. In Coal and Peat Fires: A Global Perspective; Stracher, G.B., Prakash, A., Sokol, E.V., Eds.; Elsevier: Amsterdam, The Netherlands, 2015; Volume 3, pp. 204-240.

14. Žaček, V.; Skála, R. Mineralogy of Burning-Coal Waste Piles. In Coal and Peat Fires: A Global Perspective; Stracher, G.B., Prakash, A., Sokol, E.V., Eds.; Elsevier: Amsterdam, The Netherlands, 2015; Volume 3, pp. 110-159.

15. Cobb, H.L. Cadmium Whiskers. Mon. Rev. Am. Electroplat. Soc. 1946, 33, 28.

16. Compton, K.G.; Mendizza, A.; Arnold, S.M. Filamentary Growths On Metal Surfaces-"Whiskers". Corrosion 1951, 7, 327-334. [CrossRef]

17. Sunagawa, I. Crystals: Growth, Morphology E Perfection; Cambridge Univeristy Press: Edinburgh, UK, 2007.

18. Donn, B.; Sears, G.W. Planets and Comets: Role of Crystal Growth in Their Formation. Science 1963, 140, 1208-1211. [CrossRef]

19. Noor, M.S. For nanowire growth, vapor-solid-solid (vapor-solid) mechanism is actually vapor-quasisolid-solid (vapor-quasiliquid-solid) mechanism. J. Chem. Phys. 2009, 131, 224702. [CrossRef] [PubMed]

20. Song, M.S.; Kim, Y. Growth of Bimodal Sn-Catalyzed CdS Nanowires by Using Tin Sulfide. J. Phys. Chem. C 2014, 118, 5988-5995. [CrossRef]

21. Carretero-Genevrier, A.; Mestres, N. Growth of 1-D Oxide Nanostructures. In Encyclopedia of Nanotechnology; Bhushan, B., Ed.; Springer: Dordrecht, The Netherlands, 2015; pp. 1-17.

22. Wang, F.; Dong, A.; Buhro, W.E. Solution-Liquid-Solid Synthesis, Properties, and Applications of One-Dimensional Colloidal Semiconductor Nanorods and Nanowires. Chem. Rev. 2016, 116, 10888-10933. [CrossRef]

23. Wang, H.; Fischman, G.S. Role of liquid droplet surface diffusion in the vapor-liquid-solid whisker growth mechanism. J. Appl. Phys. 1994, 76, 1557-1562. [CrossRef]

24. Trentler, T.J.; Hickman, K.M.; Goel, S.C.; Viano, A.M.; Gibbons, P.C.; Buhro, W.E. Solution-Liquid-Solid Growth of Crystalline III-V Semiconductors: An Analogy to Vapor-Liquid-Solid Growth. Science 1995, 270, 1791-1794. [CrossRef]

25. Rietveld, H.M. A profile refinement method for nuclear and magnetic structures. J. Appl. Crystallogr. 1969, 2, 65-71. [CrossRef]

26. Lee, J.-C.; Lee, W.; Han, S.-H.; Kim, T.G.; Sung, Y.-M. Synthesis of hybrid solar cells using CdS nanowire array grown on conductive glass substrates. Electrochem. Commun. 2009, 11, 231-234. [CrossRef]

27. Wagner, R.S.; Doherty, C.J. Mechanism of Branching and Kinking during VI.S Crystal Growth. J. Electrochem. Soc. 1968, 115, 7. [CrossRef]

28. Wang, Z.; Gao, F.; Zu, X.; Weber, W.J. Physical Properties of GaN Nanotubes as Revealed by Computer Simulation. In One-Dimensional Nanostructures; Wang, Z.M., Ed.; Springer: New York, NY, USA, 2008; p. 87.

29. Gautam, M.; Shi, Z.; Jayatissa, A.H. Graphene films as transparent electrodes for photovoltaic devices based on cadmium sulfide thin films. Sol. Energy Mater. Sol. Cells 2017, 163, 1-8. [CrossRef]

30. Tell, B.; Damen, T.C.; Porto, S.P.S. Raman Effect in Cadmium Sulfide. Phys. Rev. 1966, 144, 771-774. [CrossRef]

31. Scott, J.F.; Damen, T.C. Raman scattering from surface modes of small CdS crystallites. Opt. Commun. 1972, 5, 410-412. [CrossRef]

32. Abdulkhadar, M.; Thomas, B. Study of raman spectra of nanoparticles of CdS and ZnS. Nanostruct. Mater. 1995, 5, 289-298. [CrossRef]

33. Kumar, P.; Saxena, N.; Chandra, R.; Gupta, V.; Agarwal, A.; Kanjilal, D. Nanotwinning and structural phase transition in CdS quantum dots. Nanoscale Res. Lett. 2012, 7, 584. [CrossRef]

34. Trajic, J.; Gilic, M.; Romcevic, N.; Romcevic, M.; Stanisic, G.; Hadzic, B.; Petrovic, M.; Yahia, Y.S. Raman spectroscopy of optical properties in CdS thin films. Sci. Sinter. 2015, 47, 145-152. [CrossRef]

35. Contreras-Rascón, J.I.; Díaz-Reyes, J.; Flores-Pacheco, A.; Serrano-de la Rosa, L.E.; del Ángel-Vicente, P.; Lozada Morales, R.; Álvarez Ramos, M.E.; López-Salazar, P. Enhanced photoluminescence effects in nanostructured cubic CdS matrix doped with $\mathrm{Cu} 2+$ obtained by chemical Bath deposition. J. Mater. Res. Technol. 2020, 9, 364-372. [CrossRef]

36. Hope, G.A.; Woods, R.; Munce, C.G. Raman microprobe mineral identification. Miner. Eng. 2001, 14, 1565-1577. [CrossRef] 
37. Eroles, A.J.; Friedberg, A.L. Color and Structural Character of CdS-CdSe Pigments. J. Am. Ceram. Soc. 1965, 48, 223-227. [CrossRef]

38. Smoliński, A.; Rompalski, P.; Cybulski, K.; Chećko, J.; Howaniec, N. Chemometric Study of Trace Elements in Hard Coals of the Upper Silesian Coal Basin, Poland. Sci. World J. 2014, 2014, 1-12. [CrossRef] [PubMed]

39. Lemmlein, G.G. Morphology and Genesis of Crystals; Science: Moscow, Russia, 1973.

40. Zhai, T.; Fang, X.; Li, L.; Bando, Y.; Golberg, D. One-dimensional CdS nanostructures: Synthesis, properties, and applications. Nanoscale 2010, 2, 168. [CrossRef]

41. Banerjee, R.; Jayakrishnan, R.; Banerjee, R.; Ayyub, P. Effect of the size-induced structural transformation on the band gap in CdS nanoparticles. J. Phys. Condens. Matter 2000, 12, 10647-10654. [CrossRef]

42. Schwalbach, E.J.; Davis, S.H.; Voorhees, P.W.; Wheeler, D.; Warren, J.A. Liquid droplet dynamics and complex morphologies in vapor-liquid-solid nanowire growth. J. Mater. Res. 2011, 26, 2186-2198. [CrossRef]

43. Pelton, A.D.; Bale, C.W.; Moser, Z.; Zabdyr, L. Computer calculation of the Cd-Bi-Pb-Sn quaternary phase diagram. Can. Metall. Q. 1976, 15, 10. [CrossRef]

44. Cahill, J.A.; Kirshenbaum, A.D. The density of liquid bismuth from its melting point to its normal boiling point and an estimate of its critical constants. J. Inorg. Nucl. Chem. 1963, 25, 501-506. [CrossRef]

45. Givargizov, E.I. Fundamental aspects of YLS Growth. J. Cryst. Growth 1975, 31, 20-30. [CrossRef]

46. Sears, G.W. A growth mechanism for mercury whiskers. Acta Metall. 1955, 3, 361-366. [CrossRef]

47. Snugovsky, L.; Perovic, D.D.; Rutter, J.W. Experimental study of Bi-Cd-In phase diagram using conventional methods plus quenching and 'solidification path' techniques. Mater. Sci. Technol. 2000, 16, 968-978. [CrossRef]

(C) 2020 by the authors. Licensee MDPI, Basel, Switzerland. This article is an open access article distributed under the terms and conditions of the Creative Commons Attribution (CC BY) license (http://creativecommons.org/licenses/by/4.0/). 